Janusz Danieluk

Archiwum Państwowe w Białymstoku e-mail: jdanieluk@poczta.onet.pl

\title{
Funkcjonowanie notariatu w Cesarstwie Rosyjskim na przykładzie akt zespołu Starszego Notariusza Sądu Okręgowego w Grodnie
}

\begin{abstract}
Abstrakt
Artykuł porusza problematykę związaną ze zmianami systemu notarialnego w Cesarstwie Rosyjskim w II połowie XIX w. Głównym przedmiotem badania była tzw. ustawa notarialna z $1866 \mathrm{r}$. oraz jej praktyczne zastosowanie przy sporządzaniu umów notarialnych. Podstawową bazą źródłową jest zespół archiwalny: Starszy Notariusz Sądu Okręgowego w Grodnie, przechowywany w zasobie Archiwum Państwowego w Białymstoku. Autor był zainteresowany budową różnego rodzaju aktów notarialnych oraz zasadami ich zatwierdzania i wprowadzania w życie. Do najważniejszych hipotez badawczych można zaliczyć następujące pytania: W jakim stopniu ówczesny system notarialny różnił się od obowiązującego wcześniej (sprzed reformy)? Jakie były różnice pomiędzy prawem notarialnym obowiązującym w Królestwie Polskim a notariatem w zachodnich guberniach Cesarstwa? Z jakich elementów składała się struktura organizacyjna notariatu? Jakie były prawa i obowiązki starszych i „zwykłych” notariuszy? Ponadto, udało się zidentyfikować notariuszy, którzy prowadzili kancelarie na obszarze byłego obwodu białostockiego. Wszystkie osoby sprawujące urząd starszego notariusza były narodowości rosyjskiej, wyznania prawosławnego. Niektórzy z nich swoją lojalność wobec władzy carskiej okazali aktywnym uczestnictwem $\mathrm{w}$ tłumieniu powstania styczniowego.
\end{abstract}

\footnotetext{
Abstract

The functioning of the notary in the Russian Empire by the example of archival records: Senior Notary of the District Court in Grodno

The article addresses the changes that occurred in the notarial system of the Russian Empire in the second half of the 19th century. The main research objective was to
} 
conduct a detailed analysis of the Notary Act of 1866 and its practical application in notarial contracts. The source base used in the study is the archival records of the Senior Notary of the District Court in Grodno, which are preserved in the State Archive in Bialystok. The author was interested in how different kinds of notarial documents were constructed, and in the rules relating to their approval and implementation. The most important hypotheses attempted relate to the questions of: to what extent the notarial system was different from the previous regulations; what the differences were between notary legislation in the Polish Kingdom and in the Western Governorates; what elements were included in the organizational structure of the notarial system, and what the rights and obligations were of senior notaries and "regular" notaries? Through the research, the author has also managed to identify some of the notarial officials who held office in the territory of the former Belostok Oblast. All senior notaries were of Russian nationality and belonged to the Russian Orthodox faith. They were loyal to the Tsar and some of them participated in combating the January Uprising of 1863 .

Słowa kluczowe: XIX-wieczny notariat w Cesarstwie Rosyjskim, starszy notariusz, obwód białostocki, umowy notarialne

Key words: 19th-century notary of the Russian Empire, Bialystok notaries, senior notary, Belostok Oblast, notarial contract

\section{Wstęp}

Dokumentacja notarialna jest cennym materiałem źródłowym wykorzystywanym do prowadzeniu badań nad dziejami dawnego obwodu białostockiego. Akty notarialne w postaci: umów kupna-sprzedaży nieruchomości, zastawów, darowizn, testamentów, podziałów majątku, akt założycielskich spółek i towarzystw akcyjnych, tworzą bazę źródłową do badania historii gospodarczej, genealogii rodziny i rodów, dziejów urbanistyki i architektury, funkcjonowania prawa obrotu nieruchomościami ${ }^{1}$. Akty notarialne są również przedmiotem zainteresowań archiwistów badających systemy kancelaryjne i procedury wytwarzania tego typu dokumentacji ${ }^{2}$ oraz filologów i językoznawców, którzy traktują

$1 \quad$ Akta notarialne są wykorzystywane przez lokalnych historyków do badań nad dziejami majątków ziemskich, miast i miasteczek Białostocczyzny oraz znaczących rodów i rodzin Podlasia - W. Wróbel, Historia ulicy Kijowskiej. Studia z dziejów Białegostoku, Białystok 2011; idem, Kilińskiego: historia jednej ulicy, Białystok 2016; M. Wróbel, Antoni Hipolit Wieczorek (1844-1906). Rys biograficzny białostockiego fabrykanta i dzieje jego zakładu (do 1906 r.), „Rocznik Białostocki” 2017, t. XIX, s. 107-137; J. Danieluk, Niemiecka rodzina na Podlasiu - Dziedzictwo Artura Hasbacha (1864-1940), [w:] Stan badań nad wielokulturowym dziedzictwem dawnej Rzeczpospolitej, red. W. Walczak, K. Łopatecki, Białystok 2017, s. 243-268; K. Łopatecki, E. Zalewska, Historia uroczyska Jaroszówka. Badania nad przemianami własnościowo-osadniczymi na pograniczu Wasilkowa i Białegostoku, „Studia Podlaskie” 2013, nr 21, s. 68-69.

2 S. Kowalska, Podstawy prawne działania notariuszy kaliskich w okresie międzywojennym, [w:] Dziedzictwo kulturowe miasta Kalisza i regionu południowej Wielkopolski, red. W. Kowalska, Poznań Kalisz 2012, s. 149-170. 
dokument archiwalny jako gatunek wypowiedzi, charakterystyczny dla urzędowo-prawnej sfery komunikacji ${ }^{3}$.

Celem artykułu jest przedstawienie funkcjonowania instytucji notariatu po wprowadzeniu reformy sądowniczej w Cesarstwie Rosyjskim w drugiej połowie XIX w. Szczegółowej analizie poddano akt o notariacie: Bысочaŭme утверждненное положеніе о нотаріяльной части 14 Апрпля 1866 года, opublikowany w "Zwodzie Praw Imperium Rosyjskiego"4. Zapisy aktu normatywnego zostały skonfrontowane z dokumentacją wytworzoną przez urząd Starszego Notariusza przy Sądzie Okręgowym w Grodnie, która przechowywana jest w zasobie Archiwum Państwowego w Białymstoku.

Zakres terytorialny artykułu ogranicza się do obszaru byłego obwodu białostockiego, który został w 1842 r. włączony do guberni grodzieńskiej. Zawężenie obszaru badawczego do trzech zachodnich powiatów guberni grodzieńskiej (białostockiego, bielskiego i sokólskiego) uwarunkowane jest bazą źródłową, gdzie z tego obszaru wydzielony został zwarty kompleks akt jako zespół Starszego Notariusza Sądu Okręgowego w Grodnie, które stanowią podstawowy materiał źródłowy ${ }^{5}$.

Zakres chronologiczny artykułu obejmuje okres od momentu uchwalenia aktu prawnego o notariacie z 14 kwietnia 1866 r. Cezura końcowa dotyczy zakończenia działalności urzędu Starszego Notariusza Sądu Okręgowego w Grodnie na obszarze byłego obwodu białostockiego, co było związane $\mathrm{z}$ wybuchem pierwszej wojny światowej i ewakuacją urzędów gubernialnych w głąb Cesarstwa Rosyjskiego w 1915 r. $^{6}$

Dzieje instytucji notariatu oraz zasady jego funkcjonowania na ziemiach polskich nie cieszyły się dużym zainteresowaniem polskich badaczy. Zostało opublikowanych kilka monografii naukowych oraz artykułów poświęconych omawianemu zagadnieniu. Historycy koncentrowali się przeważnie na przedstawieniu regulacji prawnych kształtujących zakres funkcjonowania urzędu notariusza na przestrzeni wieków. Zwracali również uwagę na zróżnicowaną pozycję tej instytucji w poszczególnych regionach kraju. W przypadku zaboru rosyjskiego, przedmiotem badań był obszar Królestwa Polskiego. Dużo mniejszą uwagę

3 A. Dunin-Dudkowska, Akt notarialny na tle przemian historyczno-kulturowych w Polsce, „Język a Kultura" 2012, t. 23, s. 135-150.

4 Высочайще утверждненное положеніе о нотаріяльной части 14 Апргля 1866 года, [พ:] Полное собрание законов Российской империи, t. 41 (1866), nr 43186.

5 Zespół akt Starszego Notariusza Sądu Okręgowego w Grodnie jest również przechowywany w Narodowym Archiwum Historycznym Białorusi w Grodnie. Jest to fond nr 580, obejmujący lata 1883-1915 i liczy 30536 jednostek archiwalnych. Składa się z akt czynności starszego notariusza dotyczących nieruchomości położonych w sześciu wschodnich powiatach guberni grodzieńskiej (brzeskiego, grodzieńskiego kobryńskiego, prużańskiego, słonimskiego i wołkowyskiego) - J. Szumski, Inwentarz Zespołu Akt Starszy Notariusz Sadu Okregowego w Grodnie, [1581-1882] 1883-1915 [1920-1930], Białystok 2012, s. 16.

6 Rosyjskie ustawodawstwo notarialne ostatecznie zostało zniesione w momencie wejścia w życie rozporządzenia Prezydenta Rzeczypospolitej z 2 lutego 1928 r., znoszącego urząd Starszego Notariusza i wprowadzającego, we wszystkich wschodnich województwach, polski system hipoteczny. 
skupiano na systemie notarialnym obowiązującym w zachodnich guberniach Cesarstwa Rosyjskiego ${ }^{7}$.

Najważniejsze publikacje dotyczące dziejów notariatu na ziemiach polskich należą do Doroty Malec ${ }^{8}$. Niestety, problematyka związana ze zmianami $\mathrm{w}$ funkcjonowaniu urzędu notarialnego $\mathrm{w}$ zachodnich guberniach Cesarstwa Rosyjskiego przedstawiono skrótowo 9 . Autorka omówiła kilka przepisów prawnych Aktu o notariacie z 1866 r., w których podkreślała powołanie urzędu Starszego Notariusza, a także scharakteryzowała kompetencje notariuszy podlegających jurysdykcji miejscowych sądów okręgowych. Badaczka skoncentrowała się na przedstawieniu systemu notarialnego w Królestwie Polskim, który działał na odmiennych zasadach niż na pozostałym terytorium Cesarstwa Rosyjskiego.

Generalnie historycy prawa nie podjęli badań szczegółowych w tej problematyce. Przede wszystkim działalność urzędów notarialnych omawiano $\mathrm{w}$ kontekście funkcjonowania wymiaru sprawiedliwości w danym okresie ${ }^{10}$. Co oczywiste, większe zainteresowanie reformą systemu notarialnego z drugiej połowy XIX w., występuje w badaniach rosyjskojęzycznych. Popełnionych zostało kilka artykułów poświęconych wyłącznie problematyce wprowadzania zmian w ustawodawstwie sądowniczym i notarialnym w latach sześćdziesiątych XIX w. Olga Tiszkowa, w artykule odnoszącym się do ustawy notarialnej z 1866 r., przeanalizowała wybrane paragrafy tego aktu prawnego. Autorkę interesowały zagadnienia dotyczące ograniczeń narodowościowych i społecznych przy obejmowaniu stanowiska notariusza, proces rekrutacji kandydatów na omawiany urząd oraz pozycja notariuszy w hierarchii urzędniczej i społecznej w Imperium Rosyjskim $^{11}$.

Dużo miejsca instytucji notariatu poświęcali historycy-archiwiści. Akty notarialne analizowano pod kątem sposobów ich wytwarzania i obiegu dokumentacji. Przedmiotem zainteresowania badaczy był proces aktotwórczy, który omawiano opierając się na obowiązujących systemach kancelaryjnych. Archiwiści skoncentrowali uwagę na analizie konkretnych urzędów archiwalnych działających w poszczególnych regionach Królestwa Polskiego. Niewiele jest natomiast archiwalnych publikacji i artykułów dotyczących archiwaliów notarialnych

7 H. Drzewiecki, Zarys dziejów notariatu w Polsce, Warszawa 1927; S. Góra, Projekt ustawy notariatu, „Przegląd Notarialny” 1922, nr 1 s. 9-39.

8 D. Malec, Dzieje notariatu polskiego, Kraków 2007; Eadem, Notariat Drugiej Rzeczpospolitej, Kraków 2002.

9 Por. P. Fiedorczyk, Recenzja pracy: D. Malec, Dzieje notariatu polskiego, „Czasopismo Prawno-Historyczne" 2008, t. LX, z. 2, s. 409-414.

10 A. Korobowicz, W. Witkowski, Ustrój i prawo na ziemiach polskich, Lublin 1994; A. Korobowicz, Sądownictwo Królestwa polskiego, Lublin 1996.

11 О. Г. Тишкова, Положение о нотариальной части, „Гуманитарные и социальные науки” 2011, nr 5, s. 173-185; А. Фемелиди, Русский нотариат. История нотариата и действующее нотариальное положение 14 апреля 1866 г., Санкт-Петербург 1902; А. Олейнова, История становления законодательства о нотариате в России, Москва 2004. 
wytworzonych poza granicami Królestwa ${ }^{12}$. Działalność notariatu na obszarze zachodnich guberni Rosji carskiej omówiona została szczegółowo w opublikowanym inwentarzu zespołu archiwalnego akt Starszego Notariusza Sądu Okręgowego w Grodnie autorstwa Jerzego Szumskiego ${ }^{13}$. Badacz ten, we wstępie do inwentarza zespołu, omówił zadania i kompetencje instytucji Starszego Notariusza i podległych mu notariuszy miejskich i powiatowych. Przedstawił procedury zatwierdzania i archiwizowania umów notarialnych opartej na wprowadzonej w 1866 r. ustawie notarialnej. Omówił zasady sporządzania różnych typów dokumentacji notarialnej oraz wydawania z nich wypisów, odpisów i kopii. Szumski ustalił również cezurę końcową obowiązywania notarialnego prawodawstwa rosyjskiego na ziemiach polskich.

Akty notarialne były również przedmiotem zainteresowań filologów i językoznawców. Anna Dunin-Dudkowska jest autorką kilku publikacji poświęconych dokumentowi notarialnemu jako gatunkowi wypowiedzi ${ }^{14}$. Badaczka przeprowadziła analizę strukturalną różnych typów dokumentów notarialnych wyróżniając w pojedynczych aktach wzorcowe (powtarzalne) segmenty komunikatu urzędowego o charakterze kancelaryjno-prawnym. Autorka ograniczyła się do opracowania wyłącznie polskojęzycznych i dwudziestowiecznych dokumentów notarialnych. Ich struktura budowy, nieznacznie jednak odbiegała od tej jaka obowiązywała w zaborze rosyjskim. Niektóre rozwiązania analizy filologicznej, zostały zaadaptowane do przedstawienia wzorców budowy aktów notarialnych wytworzonych w rosyjskich kancelariach.

Ważną pracą na temat rosyjskiego prawa notarialnego w XIX w. jest dysertacja doktorska Mikołaja Komarowa zatytułowana: Notariat w Rossijskoj imperii wo wtoroj połowinie XIX - naczalie XX wieka (Istoriko-prawnoje isliedowanije) ${ }^{15}$. Autor prześledził najważniejsze regulacje prawne systemu notarialnego w przeciągu ostatniego półwiecza panowania dynastii Romanowów (m.in. ustawy sądowe i notarialne z: 1864, 1866, 1903 roku). Komarow był zainteresowany nie tylko rozwiązaniami prawnymi, ale i sytuacją społeczną i ekonomiczną notariuszy rosyjskich po wprowadzeniu zmian ustrojowych. Historyk dokonał analizy porównawczej zmian w prawie notarialnym $\mathrm{w}$ XIX w. w kontekście funkcjonowania notariatu w czasach wcześniejszych, poczynając od XVI w.

12 K. Nowakowski, Konferencja metodyczna dotyczaca opracowania akt notarialnych, „Archeion” 1993, I. 92, s. 192-193; R. Sikorski, Działalność kancelarii notarialnej pod koniec XIX i w pierwszych latach $X X$ wieku oraz po odzyskaniu niepodległości, $w$ świetle przepisów zachowanej dokumentacji zespotu archiwalnego: Kancelaria notariusza Stanisława Leopolda Biernackiego w Częstochowie, „Ziemia Częstochowska” 2016, t. XLII, s. 109-119; S. Kozak, Reprezentacyjność galicyjskich akt notarialnych z zasobu Archiwum Państwowego w Przemyślu, „Archeion” 1997, t. 98, s. 45-65.

13 J. Szumski, Inwentarz...

14 A. Dunin-Dudkowska, op. cit.; eadem, Akt notarialny jako gatunek wypowiedzi, Lublin 2010.

15 М. Комаров, Нотариат в Российской империи во второй половине XIX - начале XX века (Историко-правовое исследование), Москва 2004. 
Oprócz wyżej wymienionych autorów należy również wspomnieć innych historyków rosyjskich zajmujących się badaniem omawianego tematu: Konstantina Bażutowa, Aleksandra Femilidy czy Anastazji Olejnowej ${ }^{16}$.

$\mathrm{W}$ niniejszej pracy podjeto próbę ukazania specyfiki zmian w systemie notarialnym, wprowadzonych $\mathrm{w}$ wyniku reformy $\mathrm{w}$ drugiej połowy XIX w. w Cesarstwie Rosyjskim, które generowały następujące problemy i pytania badawcze:

1. Jaki był nadzór organów sądowych na działalność notariuszy?

2. Czynniki warunkujące zróżnicowanie możliwości dochodowych notariuszy.

3. Struktura umowy notarialnej na podstawie przepisów aktu prawnego z $1866 \mathrm{r}$.

4. Procedury uwierzytelnienia dokumentacji notarialnej (Kiedy akt notarialny nabierał mocy prawnej?).

5. Zasady archiwizacji aktów notarialnych.

6. Działalność Starszego Notariusza Sądu Okręgowego w Grodnie w świetle zachowanych materiałów archiwalnych.

\section{Kompetencje Starszego Notariusza}

14 kwietnia 1866 r. wprowadzono w Cesarstwie Rosyjskim reformę notarialną. Zakładała ona objęcie kontrolą działalności notariuszy przez miejscowe sądy okręgowe. Ustanowiła również nową klasyfikację notariuszy, dzieląc ich na notariuszy „zwykłych” i Starszych Notariuszy, którzy urzędowali przy archiwach notarialnych w sądach okręgowych ${ }^{17}$. Wszystkie transakcje dotyczące nieruchomości miały być sporządzane w kancelariach notarialnych, a następnie zatwierdzane i rejestrowane przez Starszych Notariuszy. Utworzenie tego urzędu było etapem reformy sądownictwa w Rosji rozpoczętej jeszcze w 1864 r. $^{18}$

$\mathrm{W}$ dotychczasowej praktyce $\mathrm{w}$ działalności sądów wyższej instancji nie przewidywano funkcji notariuszy. Przykładowo, w działającym do 1842 r. Sądzie Głównym w Białymstoku oprócz sędziów urzędowali sekretarze, protokolanci, archiwiści, registratorzy i kancelarzyści ${ }^{19}$.

Działalność Starszego Notariusza obejmowała zasięgiem obszar podlegający kompetencji sądu okręgowego. Z reguły zawierał się on $\mathrm{w}$ granicach jednej

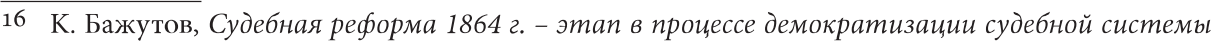
России, [w:] Судебная Реформа 1864 года и ее значение для формирования правовых систем государств постсоветского пространства: пробльемы теории и практики, Материаль XIV Международных Конивских чтений, Владивосток 2015, s. 13-19.

17 D. Malec, Dzieje notariatu..., s. 77-78; Н. Коморов, op. cit., s. 49; K. Бажутов, op. cit, s. 13-19.

18 Высочайше утвержденныя основныя положенія преобразованія судебной части вь Россіи, 29 Сентября 1862 года, [w:] Полное собрание законов Российской империи, t. 37 (1862), nr 48761, s. 145-174; H. Drzewiecki, op. cit., s. 10-11; J. Szumski, Inwentarz..., s. 7.

19 K. Łopatecki, Struktura i siedziba Sądu Głównego w Białymstoku (1808-1842), „Miscellanea Historico-Iuridica" 2017, nr XVI, z. 2, s. 28, 31-32. 
guberni. Był to urząd jednoosobowy, aczkolwiek prawo do zatwierdzania umów i rejestrowania praw do nieruchomości posiadał również pomocnik Starszego Notariusza. Starszy Notariusz jako urzędnik państwowy był zrównany, pod względem służbowym, $\mathrm{z}$ członkami sądu okręgowego, a jego pomocnik - z sekretarzem sądu. Jako pracownik sądu okręgowego posiadał stałą pensję. Mianowanie i zwalnianie Starszych Notariuszy należało do kompetencji ministra sprawiedliwości ${ }^{20}$.

W świetle ustawy notarialnej z 1866 r. do podstawowych kompetencji Starszych Notariuszy należało: zatwierdzanie umów dotyczących nieruchomości w postaci aktów kupna-sprzedaży, podziału majątku, darowizn. Prowadzili również księgi hipoteczne (кpепостныц книгu) oraz rejestr spraw dotyczących zawieranych transakcji. Wydawali świadectwa o nieruchomościach, stanowiących zabezpieczenie transakcji finansowych, sporządzali zbiory tzw. nakazów płatniczych i zwolnień od długów oraz wydawali odpisy i wypisy z ksiąg i aktów złożonych $w$ archiwum notarialnym przy sądzie okręgowym ${ }^{21}$.

Starszy Notariusz był odpowiedzialny za prowadzenie archiwum notarialnego przy sądzie okręgowym. Przechowywał w nim m.in. pieczęć archiwum ( $\mathrm{z}$ wizerunkiem godła gubernialnego oraz nazwą siedziby archiwum w otoku), egzemplarz pieczęci Starszego Notariusza z oznaczeniem jego podpisu, kopie aktów przechowywanych w archiwum, rejestr wypisów i kopii wydawanych z ksiąg aktowych, księgi nieruchomości (zawierające transakcje zatwierdzone przez Starszego Notariusza), rejestr tychże ksiąg (sporządzany oddzielnie dla każdego powiatu i miasta), wykaz wszystkich załatwionych spraw oraz księgi z rejestrem zebranych opłat skarbowych ${ }^{22}$.

\section{Prawa i obowiązki notariuszy}

Sieć notarialną, obok Starszych Notariuszy, tworzyli również notariusze działający w miastach powiatowych oraz $w$ mniejszych miasteczkach. Opierając się na materiałach archiwalnych z zasobu Archiwum Państwowego w Białymstoku, na obszarze byłego obwodu białostockiego w drugiej połowie XIX w. funkcjonowało 22 notariuszy ( 10 w Białymstoku, 7 w Bielsku oraz 5 w Sokółce). Notariusze byli mianowani przez Starszego Prezesa Izby Sądowej, na wniosek właściwego Prezesa Sądu Okręgowego. Nie musieli mieć ukończonych studiów prawniczych, jednakże kandydaci zobowiązani byli do złożenia egzaminu przed komisją w składzie: prezes sądu okręgowego, prokurator oraz Starszy Notariusz

20 Высочайще утверждненное положеніе о нотаріяльной части 14 Апргля 1866 года, [т:] Полное собрание законов Российской империи, t. 41 (1866), nr 43186, punkt: 43, s. 350; J. Szumski, Inwentarz..., s. 9; ; Н. Коморов, op. cit., 4, s. 17.

21 Высочайше утверждненное...14 Апргля 1866 года, punkty: 154, 155, 158, 159, s. 357.

22 О. Г. Тишкова, op. cit., s. 178; Высочайше утверждненное...14 Апргля 1866 года, punkty: 42, 45, s. 350 . 
urzędujący przy sądzie okręgowym. Egzamin obejmował sprawdzenie umiejętności w redagowaniu aktów oraz znajomość form postępowania notarialnego i ustaw niezbędnych przy sprawowaniu urzędu ${ }^{23}$. Dodatkowo kandydaci musieli posiadać rosyjskie pochodzenie, być niekaralnymi oraz nie mogli pełnić innych funkcji państwowych ${ }^{24}$.

Notariusze zaliczeni zostali do VIII klasy urzędników. Zrównano ich służbowo z pomocnikami sekretarzy sądów okręgowych. Nie posiadali jednak z tego tytułu prawa do urzędniczej rangi oraz emerytury. Nie przysługiwała im również stała pensja państwowa. Pomimo tych ograniczeń, mieli prawo do pobierania opłat za każdą czynność notarialną 25 .

Notariusze urzędowali w miastach gubernialnych i powiatowych. W pozostałych miejscowościach uprawnienia do zatwierdzania autentyczności aktów posiadali sędziowie pokoju ${ }^{26}$. Notariusze nie mogli zasiadać w ławie przysięgłych oraz prowadzić działalności adwokackiej. Za długoletnią (ponad 35-letnią) działalność mogli ubiegać się o order św. św. Anny i Włodzimierza ${ }^{27}$.

Urzędnicy notarialni mieli obowiązek obsłużenia wszystkich klientów, bez względu na ich miejsce zamieszkania. Jednakże nie mogli wykonywać czynności notarialnych poza obszarem jurysdykcji macierzystego sądu okręgowego, któremu podlegali ${ }^{28}$. Ponadto, zobowiązani byli przebywać w swoich kantorach (kancelariach notarialnych) przynajmniej przez 6 godzin dziennie. Zezwolenie na opuszczenie kantoru wydawał przedstawiciel miejscowego sądu okręgowego ${ }^{29}$.

Akt o notariacie z 1866 r. nakładał na notariuszy obowiązek sporządzania, na wniosek osób zainteresowanych: umów kupna-sprzedaży, zaświadczeń

23 D. Malec, op. cit., s. 79.

24 Высочайше утверждненное...14 Апрпля 1866 года, punkt: 5, s. 346; K. Grzybowski, Historia państwa i prawa Polski, t. 4, Warszawa 1982, s. 218-219.

25 О.Г. Тишкова, op. cit., s. 174; Высочайше утверждненное...14 Апргля 1866 года, punkty: 17, 18, s. 346-348; Н. Коморов, op. cit., s. 10.

26 Высочайше утверждненное... 14 Апрпля 1866 года, punkty: 2, 3, 19, 20 s. 346-348; О.Г. Тишкова, op. cit., s. 180 .

27 Order św. Włodzimierza był przyznawany za zasługi wojskowe i cywilne Imperium Rosyjskiego. Został ustanowiony w 1782 r. prze carycę Katarzynę II. Poświęcony był pamięci prawnuka Ruryka - św. Włodzimierza, który wprowadził chrześcijaństwo do Rusi Kijowskiej. Order św. Włodzimierza IV klasy został ustanowiony w 1816 r. i nadawano go urzędnikom państwowym za 35-letnią „nieskazitelną służbę”. Funkcjonariusz państwowy nabywał w ten sposób prawo „dziedziczonego szlachectwa” . Od 1900 r. car Mikołaj II pozbawił kawalerów orderu IV klasy przywileju uzyskania szlachectwa.

28 Высочайще утверждненное... 14 Апрпля 1866 года, punkt: 21, s. 348.

29 Высочайше утверждненное... 14 Апргля 1866 года, punkty: 37, 39, s. 349; M. Nowak, M. Ruszkowska, Notariusze sądu okręgowego i sądów pokoju guberni kieleckiej w latach 1876-1915 - próba charakterystyki środowiska, [w:] Dzieje biurokracji na ziemiach polskich, red. A. Górak, Lublin Siedlce 2008, s. 350-351. 
dotyczących nieruchomości, testamentów, darowizn, zastawów, wypisów i kopii z ksiąg aktowych. Ponadto przechowywali dokumenty powierzone im przez klientów. Notariusze sporządzali również dokumentację ewidencyjną $\mathrm{w}$ postaci:

1) rejestru opracowanych aktów, protestów i zaświadczeń oraz dokumentów umów i pożyczek;

2) dwóch ksiąg aktowych służących do wprowadzenia aktów. Pierwsza księga dotyczyła jedynie nieruchomości, druga - wszystkich pozostałych spraw;

3) księgi z rejestrem pobranych opłat;

4) alfabetycznego rejestru sporządzonych aktów i zaświadczeń;

5) wykazu wszystkich dokumentów przechowywanych przez notariusza ${ }^{30}$.

Rejestr notarialny i księgi aktowe były wydawane notariuszom wraz ze sznurem zabezpieczającym oraz pieczęcią i lakiem przez sekretarza sądu okręgowego. Wspomniana księga rejestrów notarialnych zawierała dane rubrykowe o następujących tytułach:

a) numery porządkowe;

b) data dzienna sporządzenia aktu (w układzie chronologicznym);

c) imiona, nazwiska, stan społeczny oraz miejsce zamieszkania osób, którym sporządzono akt, poświadczenie lub protest;

d) krótki opis aktu, numer aktu, pod którym figurował w księdze aktowej, wysokość wniesionych opłat;

e) wykaz osób, którym wydano wypis lub zaświadczenie z księgi aktowej.

Poniżej został zamieszczony fragment księgi rejestrów aktów notarialnych z 1889 r. bielskiego notariusza Chryzanta Smogorzewskiego (Ilustracja 1$)^{31}$.

Po corocznym zamknięciu księgi aktowej z rejestrem, notariusz zobowiązany był przekazać je do archiwum notarialnego przy sądzie okręgowym. Przekazywana księga winna była posiadać, na ostatniej stronie, zliczoną liczbę aktów oraz pozycji w rejestrze. Starszy Notariusz własnoręcznym podpisem zatwierdzał przekazane księgi ${ }^{32}$.

30 Высочайще утверждненное... 14 Апрпля 1866 года, punkt: 26, s. 348.

31 Archiwum Państwowe w Białymstoku (dalej: APB), Notariusz Chryzant J. Smogorzewski, nr zesp. 560 , sygn. $5, \mathrm{k} .1 \mathrm{v}$.

32 Высочайше утверждненное... 14 Апрпля 1866 года, punkty:27, 34, 35, s. 349. 
Ilustracja 1. Fragment księgi rejestrów aktów notarialnych z 1889 r. bielskiego notariusza Chryzanta Jakowlewicza Smogorzewskiego, z zasobu Archiwum Państwowego w Białymstoku, Notariusz Chryzant J. Smogorzewski, nr zesp. 560, sygnatura: 5, karta: 1v.

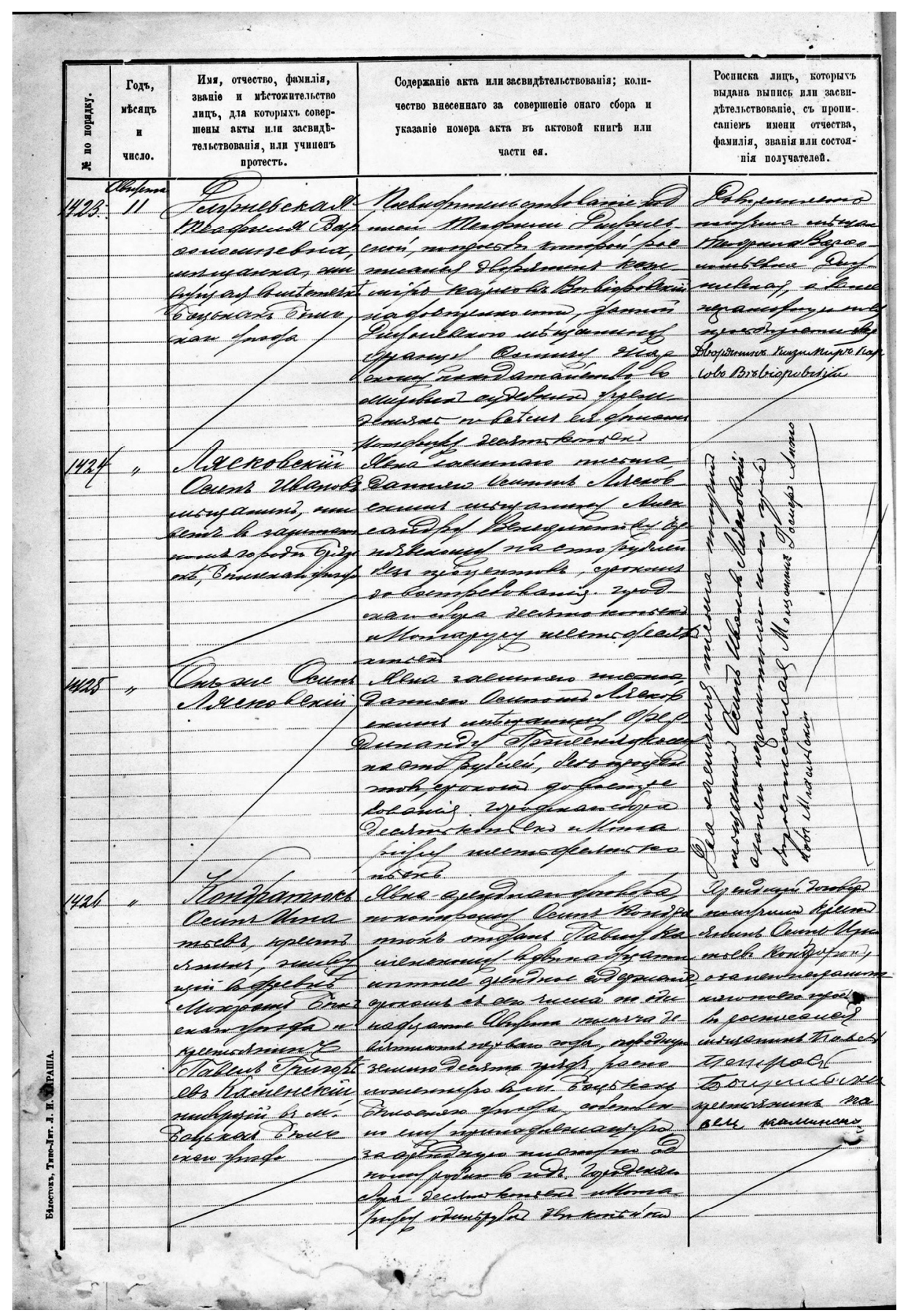




\section{Zasady zatwierdzania i rejestracji umów notarialnych w kancelarii Starszego Notariusza}

Każda umowa dotycząca nieruchomości, sporządzona w kancelarii notarialnej była w ciągu roku przesłana do właściwego urzędu Starszego Notariusza $\mathrm{w}$ celu jej zatwierdzenia i rejestracji ${ }^{33}$. Ustawa notarialna $\mathrm{z} 1866 \mathrm{r}$. przewidywała unieważnienie aktu w sprawach nieruchomości w dwóch przypadkach: jeżeli strona zbywająca lub obciążająca prawo własności nie była właścicielem danego majątku ${ }^{34}$ oraz gdy wykryto zadłużenie, którego nie wymieniono w umowie. Od decyzji Starszego Notariusza przysługiwało stronom prawo odwołania się do właściwego sądu okręgowego ${ }^{35}$.

Wpisy aktów sporządzonych przez notariuszy w danym okręgu sądowym i przesłane do zatwierdzenia były gromadzone w księgach nieruchomości - крепостная книга, które zakładano corocznie, oddzielnie dla każdego powiatu oraz miasta powiatowego ${ }^{36}$. Z kolei $\mathrm{w}$ rejestrach wieczystych - peecmp крепостных дел, również prowadzonych oddzielnie dla każdego miasta powiatowego i powiatu, odnotowywano: nazwę nieruchomości, adres, nazwisko właściciela, wszelkie zmiany i ograniczenia prawa własności oraz wpisywano regestry zatwierdzonych umów notarialnych ${ }^{37}$.

Niezależnie od ksiąg aktów wieczystych umowy nadsyłane do urzędu Starszego Notariusza w celu zatwierdzenia gromadzone były w tzw. aktach czynności. Zakładane były na każdą oddzielną sprawę i zawierały - obok treści umowy - korespondencję i dodatkową dokumentację niezbędną do jej zatwierdzenia. Obwoluty akt posiadały adnotacje o numerze, pod którym odnotowywano zatwierdzoną umowę w księdze wieczystej, a wpis tej umowy wewnątrz poszytu $\mathrm{z}$ daną sprawą zawierał także informację o stronie i numerze, pod którym umieszczono pierwszy jej wpis w księdze wieczystej.

Po zatwierdzeniu umowy notarialnej i wpisaniu tej decyzji do rejestru wieczystego strona otrzymywała jej wypis z formułą, która w tłumaczeniu na język polski brzmi następująco: „wypis ten zgodny słowo w słowo z aktem wniesionym do księgi wieczystej, zapisanym w księdze wpisów i kopii za ... rok pod $\mathrm{nr}$... Odnotowany w rejestrze wieczystym dla powiatu ..., stronica ... i wydany data". Wypis aktu notarialnego, wraz z powyższą formułą, był dokumentem wiary

33 Высочайще утверждненное... 14 Апрнля 1866 года, punkt: 161, s. 358.

$34 \mathrm{~W}$ rosyjskim prawie notarialnym nie obowiązywała zasada rękojmi wiary publicznej, która zakładała, że osoba nabywająca nieruchomość może stać się jej właścicielem, pomimo, że nie posiadała wiedzy o faktycznym jej właścicielu.

35 J. Szumski, Inwentarz..., s. 8.

36 Zespół akt Starszego Notariusza Sądu Okręgowego w Grodnie (dalej: APB SNSOG) obejmuje dokumentację wytworzoną przez notariuszy z trzech zachodnich powiatów guberni grodzieńskiej: białostockiego, bielskiego i sokólskiego. Dodatkowo wyodrębniono akty notarialne dla miast powiatowych: Białegostoku, Bielska Podlaskiego i Sokółki.

37 D. Malec, op. cit., s. 80. 
publicznej i stanowił podstawę do dokonania wszelkich rodzajów czynności urzędowych związanych z daną nieruchomością ${ }^{38}$.

Ilustracja 2. Obwoluta akt sprawy notarialnej zarchiwizowanej w archiwum Starszego Notariusza przy sądzie okręgowym. Sprawa dotyczy wprowadzenia Iwana Tarasewicza we własność nieruchomości w powiecie sokólskim z 24 maja 1913 r. W lewym górnym rogu znajduje się numer, pod którym odnotowano sprawę w rejestrze wieczystym: nr 4246 - z zasobu Archiwum Państwowego w Białymstoku, Starszy Notariusz Sądu Okręgowego w Grodnie, nr zesp. 280, sygnatura: 350 , karta: 12

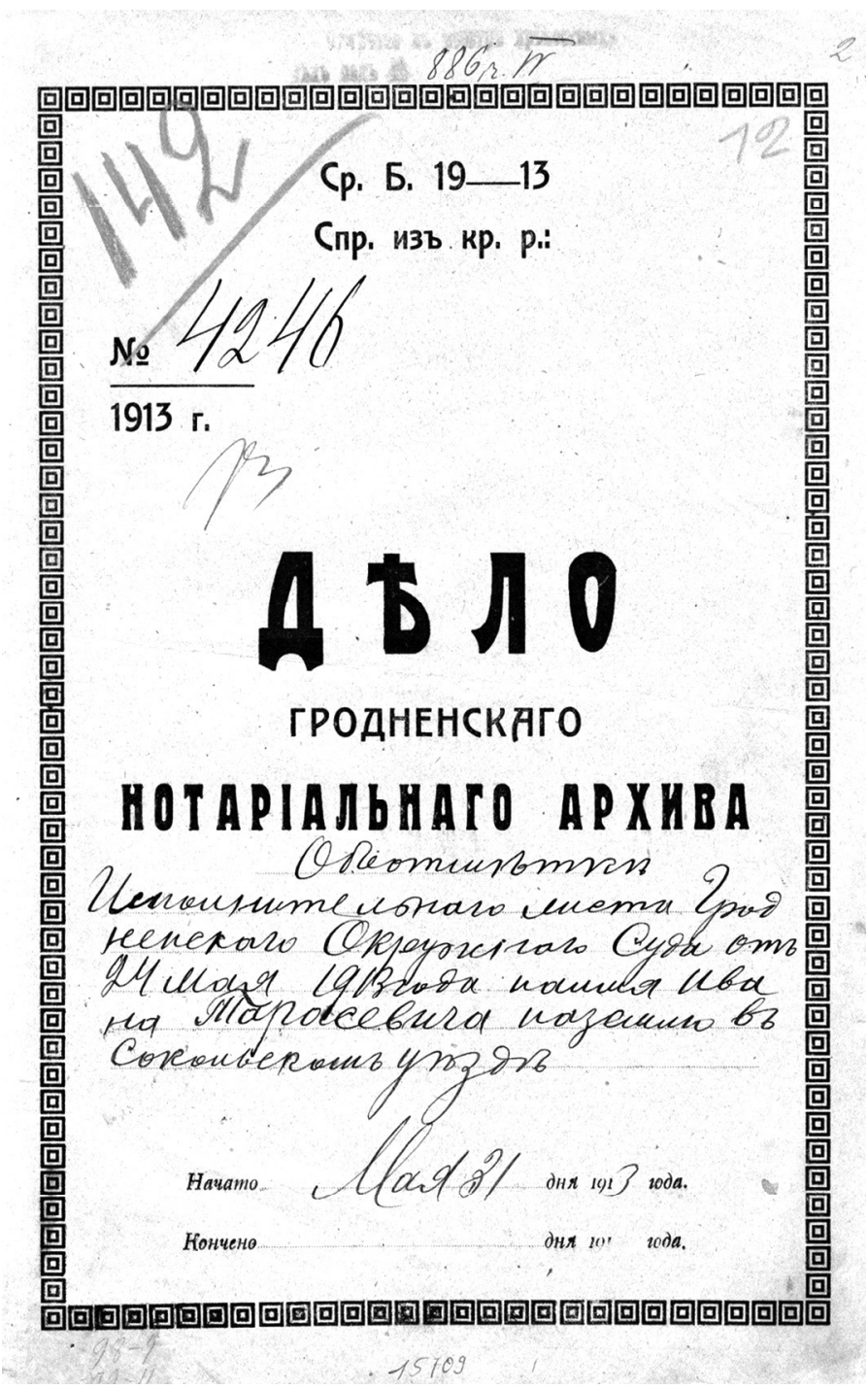

38 J. Szumski, Inwentarz..., s. 9 . 


\section{Procedury sporządzania aktu notarialnego}

Podczas sporządzania wypisu, kopii lub zaświadczenia notariusze zobowiązani byli zaopatrzyć je w pieczęć $\mathrm{z}$ wizerunkiem herbu guberni. W otoku pieczęci zamieszczano informacje odnośnie imienia i nazwiska notariusza oraz nazwy miasta lub powiatu, w którym urzędował. Wpisywano również numer, pod którym akt figurował w rejestrze oraz datę wydania dokumentu. Akty zapisywane na kilku stronach były przesznurowywane, numerowane i zabezpieczone przez notariusza ${ }^{39}$.

Wszystkie akty i poświadczenia opracowywane przez notariusza zawierały informacje odnośnie: daty dziennej sporządzenia dokumentu, imienia, nazwiska, otczestwa notariusza, miejsca zamieszkania oraz jego własnoręczny, czytelny podpis. Ponadto, wprowadzano dane o stronach zawierających transakcję na podobnym poziomie szczegółowości: imienia, nazwiska, otczestwa, stanu społecznego, miejsce zamieszkania. W przypadku osób biorących udział w spisywaniu aktu, których tożsamość nie była znana, ich dane osobowe poświadczały dwie inne osoby znane notariuszowi. Informacja o poświadczeniu tożsamości znajdowała się w treści aktu. Ustawa zakazywała notariuszowi wykonywania świadczeń notarialnych wobec własnej rodziny pod sankcją nieważności transakcji ${ }^{40}$.

Podczas zawierania umowy kupna-sprzedaży wymagana była obecność trzech świadków. Świadkami mogły zostać wyłącznie osoby pełnoletnie, piśmienne i znane notariuszowi osobiście lub przedkładające dokumenty tożsamości. Rolę świadków nie mogli pełnić: niewidomi, niesłyszący, niemi, niezrównoważeni, psychicznie chorzy, nieznający języka rosyjskiego, spokrewnieni z notariuszem lub osobami zawierającymi transakcję oraz zatrudnieni w kantorze notariusza ${ }^{41}$.

Osoby zawierające umowę, prezentowali notariuszowi projekt transakcji oraz warunki, które mają spełnić obie strony. $\mathrm{W}$ treści projektu wymieniano wszystkie dokumenty niezbędne do realizacji transakcji: pełnomocnictwa, dowody tożsamości i inne. Notariusz musiał zapytać ustnie uczestników transakcji, czy rozumieją zamysł i znaczenie zaproponowanego projektu oraz czy działają $\mathrm{w}$ dobrej wierze. Projekt umowy był odczytywany przez notariusza stronom oraz świadkom. Wszelkie poprawki, dopiski naniesione w akcie omawiano na końcu dokumentu. Po uzyskaniu akceptacji osób zainteresowanych oraz wniesieniu opłat notarialnych, projekt aktu włączano do księgi aktowej. Na dokumencie swoje podpisy składali uczestnicy oraz świadkowie zawarcia transakcji ${ }^{42}$.

\footnotetext{
39 Высочайше утверждненное...14 Апрпля 1866 года, punkty: 68, 69, s. 352.

40 Ibidem, punkty: $72,73,74,75$, s. 352.

41 Ibidem, punkty: 84,87, s. 353 .

42 Ibidem, punkty: $88,89,93,95,96,101,104,112$, s. 353-354.
} 
Wypis aktu lub jego kopia mogły zostać sporządzone tylko uczestnikowi transakcji lub osobom upoważnionym. Wydanie wypisu lub kopii każdorazowo było rejestrowane przez notariusza w księgach aktowych przez naniesienie imienia i nazwiska osoby, która kopię lub wypis otrzymała ${ }^{43}$. Ponadto, w trakcie wydawania aktu, notariusze opatrywali je pieczęcią z wizerunkiem gubernialnego herbu. W otoku pieczęci zamieszczone było imię i nazwisko notariusza oraz nazwa miasta lub powiatu, w którym urzędował (ilustracje: 3 i 4$)^{44}$.

Ilustracja 3. Uwierzytelniająca pieczęć tuszowa notariusza grodzieńskiego Konstantego Basnina.

$\mathrm{W}$ otoku zamieszczona informacja o właścicielu pieczęci oraz siedzibie jego urzędowania. $\mathrm{Na}$ środku pieczęci znajduje się wizerunek herbu guberni grodzieńskiej. Z lewej strony pieczęci widnieje własnoręczny podpis notariusza - z zasobu Archiwum Państwowego w Białymstoku, Starszy Notariusz Sądu Okręgowego w Grodnie, nr zesp. 280, sygnatura: 287, k. 113v.

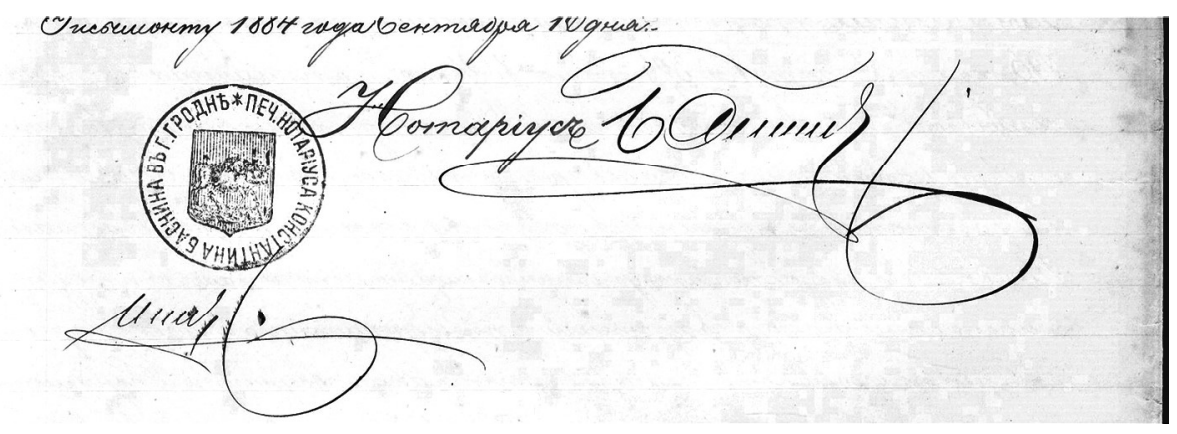

Ilustracja 4. Pieczęć lakowa uwierzytelniająca i zabezpieczająca akta sprawy prowadzonej przez notariusza grodzieńskiego Konstantego Basnina. Obok pieczęci odręcznie zapisana informacja o zabezpieczeniu dokumentów poprzez nadanie numeracji pojedynczym stronom, przesznurowanie akt spraw i zalakowaniem pieczęcią własnościową notariusza, z zasobu Archiwum Państwowego w Białymstoku, Starszy Notariusz Sądu Okręgowego w Grodnie, nr zesp, 280, sygnatura: $287, \mathrm{k} .113 \mathrm{v}$.

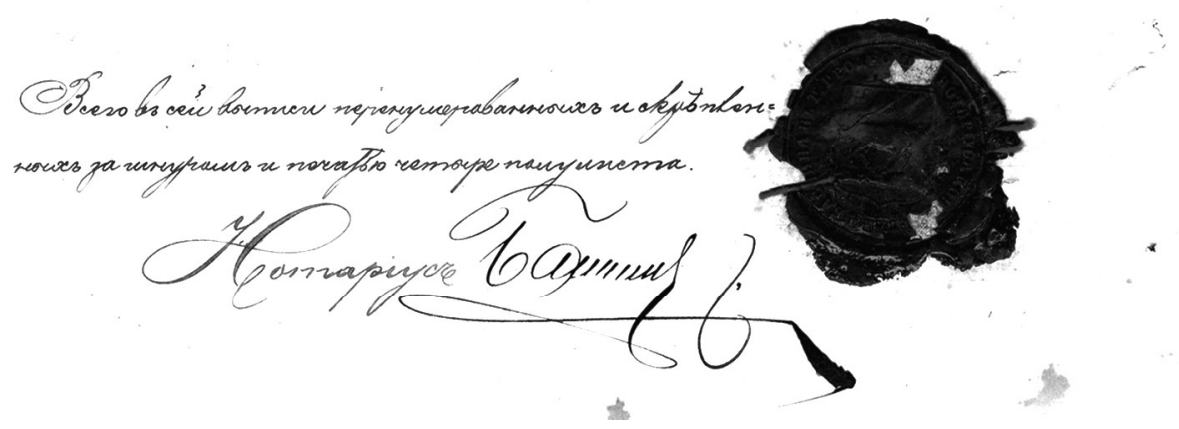

43 Wypisy akt mogły być sporządzane, w wyjątkowych przypadkach, dla sądów. Służyły one jako materiał dowodowy w toczących się sprawach - Высочайще утверждненное... 14 Априля 1866 года, punkty: $116,122,124,136$, s. 355.

44 Высочайще утверждненное...14 Апргля 1866 года, punkty: 24, 25, s. 348. 
Notariusze mogli również wystawiać (na wniosek) poświadczenia dotyczące: wierności kopii z oryginałem, autentyczności podpisów na dokumencie, figurowaniu danej osoby w ewidencji żywych, terminów złożenia dokumentów w kantorze notariusza.

Starszy Notariusz był informowany przez podległych mu notariuszy o sporządzeniu każdej umowy notarialnej. Sporządzony akt notarialny lub jego wypis z księgi aktowej, aby nabrał mocy prawnej, musiał zostać zatwierdzony w ciągu roku przez Starszego Notariusza, który sprawdzał autentyczność dostarczonego dokumentu poprzez zliczenie podpisów i pieczęci notariusza wystawiającego dokument. Starszy Notariusz weryfikował również stan zadłużenia lub ewentualnie inne obciążenia ciążące na nieruchomości. W przypadku pozytywnego sprawdzenia, pobierał opłaty skarbowe (почлины) oraz sporządzał na wypisie nadpis o zatwierdzeniu dokumentu. Następnie uzupełniał rejestr hipoteczny o dane dotyczące: nabywcy, numeru aktu w księdze nieruchomości oraz daty jego ustanowienia.

Ustawa z 1866 r. uwzględniała możliwość złożenia skargi na działalność notariuszy. Zażalenie należało skierować, w ciągu dwóch tygodni (od momentu sporządzenia aktu notarialnego) do sądu okręgowego. Adresatem skargi byli bezpośrednio notariusze, którzy zobowiązani zostali do ustosunkowania się wobec niej w ciągu siedmiu dni ${ }^{45}$.

\section{Opłaty notarialne}

Realizacja transakcji notarialnych wiązała się z różnego typu opłatami ciążącymi na jej uczestnikach. Na koszty sporządzenia aktu wpływały dwa czynniki: cena urzędowego papieru (гербовая бумага) i rodzaj dokumentu. Pobierane były należności związane z opłatą stemplową przy sporządzeniu aktu, opłatą od aktów notarialnych oraz płacą notariusza za wykonanie czynności notarialnych w postaci sporządzenia: aktu, poświadczenia, wydania kopii i wypisu z notarialnego archiwum oraz za wykonanie wypisów i kopii z ksiąg i rejestrów wieczystych. Podczas zatwierdzenia transakcji dotyczących nieruchomości należało wpłacić odrębną poszlinę w wysokości 3 rubli za każdą stronę aktu. Dochód z opłat skarbowych trafiał do miejscowej izby skarbowej. Taksa należna notariuszom była ustalana przez porozumienie między Ministerstwami: Finansów, Spraw Wewnętrznych i Sprawiedliwości. Dochód roczny notariuszy urzędujących w stolicy i miastach gubernialnych oscylował w granicach 2400 rubli, a w miastach powiatowych wynosił do 1200 rubli $^{46}$. Wynagrodzenie notariuszy

45 Высочайще утверждненное...14 Апрпля 1866 года, punkty: 62, 63, 64, 128, 161, 165, 168, 169, s. $352,356,358$.

46 R. Sikorski, op. cit., s. 112-113; D. Malec, Notariat w II Rzeczpospolitej, s. 112; Bыıcoчaŭme утверждненное...14 Апрпля 1866 года, punkty: 209, 210, s. 361. 
było porównywane z pensją, którą otrzymywali urzędnicy pracujący w sądownictwie ${ }^{47}$. W urzędach gubernialnych wynagrodzenie zbliżone do notariuszy otrzymywali: dyrektor wydziału: 2500 rubli, inżynier gubernialny - 1300 rubli, naczelnik więzienia gubernialnego - 1000 rubli. Płaca notariuszy była stosunkowa wysoka $\mathrm{w}$ porównaniu z pensją funkcjonariuszy miejskich ${ }^{48}$. Uwzględniając takie czynniki jak siła nabywcza rubla, ceny produktów spożywczych i przemysłowych, wysokość czynszów oraz opłat za wynajem nieruchomości, należy stwierdzić, że wykonywanie zawodu notariusza było stosunkowo intratnym zajęciem ${ }^{49}$.

\section{Charakterystyka archiwalno-ustrojowa zespołu: Starszy Notariusz Sądu Okręgowego w Grodnie}

W guberni grodzieńskiej urząd Starszego Notariusza przy Sądzie Okręgowym w Grodnie utworzono dopiero w 1883 r. Spowodowane to było późnym wprowadzeniem $\mathrm{w}$ życie reformy sądownictwa w dziewięciu zachodnich guberniach. Urząd Starszego Notariusza przy Sądzie Okręgowym w Grodnie funkcjonował do połowy 1915 r. Formalnie jednak nie został zlikwidowany. Działalność wznowił po odzyskaniu przez Polskę niepodległości i utworzeniu w 1919 r. grodzieńskiego okręgu sądowego. Ustawa z 31 lipca 1919 r. o utworzeniu białostockiego okręgu sądowego na obszarze zachodnich powiatów byłej guberni grodzieńskiej: białostockim, bielskim i sokólskim wprowadziła tam jako obowiązujący - system hipoteczny oparty na ustawie z $1818 \mathrm{r}^{50}$

$\mathrm{Na}$ terenie państwa polskiego urzędy Starszych Notariuszy przetrwały do 1928 r. Ich działalność została na krótko przerwana rozporządzeniem Komisarza Generalnego Ziem Wschodnich z 1 kwietnia 1920 r. o zniesieniu na wschodnich terenach Polski aktów wieczystych i systemów notarialnej rejestracji. Jednak

47 W 1908 r. sędzia śledczy zarabiał 2400 rubli, sekretarz sądu okręgowego - 1500 rubli. Natomiast pomocnik sekretarza oraz tłumacz przy izbach sądowych -1000 rubli. S. Siegel, Ceny w Warszawie w latach 1816-1914, Poznań 1949, s. 114-120.

48 Dla porównania, płaca roczna kasjera zarządu miejskiego w Warszawie w 1864 r. wynosiła 1200 rubli, $\mathrm{z}$ kolei miejskiego buchaltera - 1000 rubli. Z zarobkami zarządu kontrastowała płaca urzędników magistrackich niższego szczebla: kancelistów i pisarzy, których pensja oscylowała wokół 210-230 rubli. S. Siegel, op. cit., s. 124-126.

49 W drugiej połowie XIX w. roczna opłata czynszowa ciążąca na jednopokojowym mieszkania w Warszawie wynosiła przeciętnie ok.o 60 rubli. Ceny wybranych produktów spożywczych kształtowały się w sposób następujący: 1 funt (ok. 0,4 kg) chleba pytlowego - 4 ruble, 1 funt wieprzowiny - 13 rubli, 1 funt masła - 34 kopiejki. A. Chwalba, Imperium korupcji w Rosji i Królestwie Polskim w latach 1861-1917, Kraków 2006, s. 223-227.

50 Ustawa hipoteczna z 1818 roku nadawała notariuszom w miastach, w których znajdowały się trybunały cywilne tytuł rejentów kancelarii ziemskich. Notariuszy połączono z organizacją hipoteki. Akta i wnioski hipoteczne stawały się dokumentami wiary publicznej po zatwierdzeniu ich przez zwierzchność hipoteczną. Natomiast według ustawy z 1866 r. wypisy wydawane przez notariusza miały charakter akt wieczystych. Instytucja hipoteki w zachodnich guberniach Cesarstwa Rosyjskiego wówczas nie funkcjonowała. R. Sikorski, op. cit., s. 43; 
w listopadzie 1920 r. przywrócono dawny rosyjski tryb zatwierdzania umów notarialnych dotyczących nieruchomości zachowując - równolegle - system hipoteczny. Urzędnicy, którzy zatwierdzali i rejestrowali akty na podstawie rosyjskiej ustawy notarialnej z 1866 r. nosili po 1920 r. nazwę „zastępców starszych notariuszy”. Urzędy zastępców Starszych Notariuszy istniały przy sądach okręgowych w: Grodnie, Łucku, Nowogrodku i Pińsku. Rozporządzenie Prezydenta Rzeczypospolitej z 2 lutego 1928 r. znosiło te urzędy, wprowadzając we wszystkich wschodnich województwach polski system hipoteczny ${ }^{51}$.

Zespół akt Starszego Notariusza Sądu Okręgowego w Grodnie, przechowywany w zasobie Archiwum Państwowego w Białymstoku, obejmuje dokumentację wytworzoną w okresie 1883-1915 r. Dokumenty wcześniejsze (z lat 1581-1882) sporządzone zostały przez władze administracyjne, sądowe i osoby prywatne. Dokumentowały one prawo do własności i były dołączane do akt spraw. Z kolei akty z okresu 1920-1930 składają się z korespondencji kierowanej do Wydziału Hipotecznego Sądu Okręgowego w Białymstoku przez osoby zainteresowane.

Zespół nie obejmuje ksiąg i rejestrów wieczystych oraz dokumentacji ewidencyjnej funkcjonującej w registraturze urzędu. Zachowane dokumenty tworzą akta czynności Starszego Notariusza, które stanowią typowe akty spraw zakładane w kancelarii. Sygnaturą akt był numer, pod którym zarejestrowano sprawę w obrębie roku. Obwoluty akt posiadały adnotacje o numerze, pod którym odnotowywano zatwierdzoną umowę notarialną w rejestrze wieczystym. Dokumentacja wytworzona w kancelarii urzędu Starszego Notariusza w Grodnie dotyczyła wyłącznie nabycia, zbycia i ograniczenia praw własności do nieruchomości. Najczęściej występują akty kupna-sprzedaży, które można podzielić na dwie kategorie: купчая крепость і данная крепость. Pierwsze obejmowały typowe umowy kupna-sprzedaży. Natomiast Данная крепость dotyczyła umów, na podstawie których zmiana prawa własności odbywała się w trybie przymusowym $^{52}$.

Część akt tworzyło заставные крепости. Związane były z zaciąganiem przez właściciela nieruchomości kredytu przez tzw. akt zastawu. W zespole występują również akta darowizn - дарственныя записи, podziału nieruchomości otrzymanej w spadku - раздельная записъ oraz testamenty. W przypadku

51 S. Góra, Projekt ustawy notarjatu, „Przegląd Notarialny” 1922, nr 1, s. 9-39; J. Szumski, Inwentarz..., s. 9-10.

52 Przykładem pierwszego typu umowy kupna-sprzedaży jest transakcja zawarta w 1891 r., dotycząca nabycia przez fabrykanta Artura Hasbacha od hrabiny Zofii Rydygier - właścicielki dóbr dojlidzkich, ponad 15 dziesięcin gruntów, na których znajdowały się zabudowania fabryki włókienniczej, należącej do niemieckiego fabrykanta - APB SNSOG, sygn. 134, k. 79-82. Natomiast przykładem umowy przymusowej sprzedaży jest transakcja zbycia majątku instrukcyjnego Straż (w powiecie sokólskim) należącego do registratora kolegialnego Hieronima Michajłowicza Żiramskiego na rzecz ziemianki Marii Androsiuk, w poczet spłacenia zaległych długów. 1892 r. - APB SNSOG, sygn. 296, k. 115-116v. 
testamentów Starszy Notariusz rejestrował wyrok Sądu Okręgowego w Grodnie w sprawie ich zatwierdzenia ${ }^{53}$.

\section{Budowa dokumentów notarialnych na przykładzie akt zespołu Starszego Notariusza Sądu Okręgowego w Grodnie}

Analizie zostały poddane wybrane akty notarialne z zespołu Starszego Notariusza Sądu Okręgowego w Grodnie. Wytypowane dokumenty w postaci umowy kupna-sprzedaży nieruchomości, testamentu, aktu darowizny, należą do materiałów notarialnych typowych. Strukturę pojedynczego dokumentu notarialnego można podzielić na kilka segmentów, które są typowe dla tego typu dokumentacji:

1. dane nagłówkowe;

2. informacje personalne oraz adresowe notariusza;

3. informacje personalne uczestników czynności prawnej;

4. sposób ustalenia tożsamości stawających przez notariusza;

5. oświadczenie woli stawających i inne informacje, oświadczenia, postanowienia, zobowiązania, realizacji określonej czynności prawnej;

6. stwierdzenie o odczytaniu, przyjęciu i podpisaniu aktu notarialnego;

7. wykaz osób stawających do aktu notarialnego, którzy złożyli podpisy;

8. postanowienia dotyczące opłat i podatków;

9. podpis notariusza ${ }^{54}$.

Pierwsze cztery elementy dotyczą komparycji aktu notarialnego, która pełni rolę „wstępu” poprzedzającego treść właściwą dokumentu prawnego. Komparycja jest etapem przygotowawczym, prowadzącym do punktu kulminacyjnego całej czynności prawnej, którego zwieńczeniem jest oświadczenie woli osób fizycznych lub reprezentantów instytucji (np. towarzystwo akcyjne, koleje państwowe) posiadających zdolność do czynności prawnych. Obejmuje dane nagłówkowe, delimitacje czasowe i przestrzenne, imię i nazwisko oraz dane adresowe notariusza, informacje personalne odnoszące się do pozostałych uczestników aktu notarialnego oraz informacje notariusza o sposobie ustalenia tożsamości tych osób ${ }^{55}$. Po komparycji zamieszcza się treść zasadniczą umowy notarialnej. Ten fragment aktu zawiera informacje o postawie prawnej, na mocy której czynność notarialna może zostać zrealizowana. Ostatnie elementy aktu notarialnego dotyczą deklaracji notariusza o odczytaniu projektu umowy, częściowym powtórzeniem informacji zawartych $w$ komparycji, a mianowicie ponowne wymie-

53 J. Szumski, Inwentarz..., s. 13-14.

54 A. Dunin-Dudkowska, Akt notarialny..., s. 83; W. Chojnowski, A. Jarzęcki, Wzory aktów i innych dokumentów notarialnych, Warszawa 1971, s. 40-42, 63-66.

55 A. Dunin-Dudkowska, Akt notarialny..., s. 102. 
nienie uczestników transakcji. Ponadto zamieszcza się kompleksowe informacje o wszystkich opłatach ciążących na zleceniodawcach. Finalnym elementem projektu umowy jest własnoręczny podpis notariusza oraz pieczęć notarialna uwierzytelniająca umowę.

\section{Umowa kupna-sprzedaży}

Analizie poddano umowę sprzedaży z 16 sierpnia 1890 r. działki ziemi o powierzchni 9 dziesięcin (około 9,8 ha) położonej w uroczysku „Dubowik”, należącej do majątku instrukcyjnego Słójka, w powiecie sokólskim ${ }^{56}$. Sprzedawcą nieruchomości ziemskiej był Stanisław Andrejewicz Truskowski - pełnomocnik rzeczywistego radcy stanu - Aleksandra Aleksandrowicza Annienkowa, właściciela majątku. Nabywczynią działki była włościanka Karolina Andrejewa Łuszczewska, zamieszkała we wsi Dubowik. Nieruchomość została sprzedana za cenę 700 rubli srebrem ${ }^{57}$.

Pierwsza część komparycji aktu - dane nagłówkowe - składają się z następujących elementów: znaczek skarbowy (гербовая марка) - zamieszczony w lewym górnym rogu aktu (1a), na którym odciśnięto pieczęć okrągłą notariusza, sporządzającego umowę (1b). W otoku pieczęci wpisano imię i nazwisko notariusza oraz rejon jego działania (nazwa powiatu). W środkowej części nagłówka zapisana jest informacja o formie kancelaryjnej sporządzonego dokumentu: wypis, kopia lub zaświadczenie. W przypadku wypisu - nazwa księgi aktowej nieruchomości, z której sporządzono wypis, z uwzględnieniem daty rocznej, paginacji stron oraz numeru aktu w księdze (1c i 1d).

Sporządzanie aktów notarialnych odbywało się w kantorze notariusza lub $\mathrm{u}$ osób prywatnych, z zastrzeżeniem akt dotyczących ograniczenia praw własności. Dokumentacja tego typu miała być spisywana wyłącznie u notariuszy ${ }^{58}$. Dalsza część komparycji zawierała informacje na temat: daty i miejsca spisania aktu oraz imienia i nazwiska notariusza sporządzającego dokument $\mathrm{z}$ wyszczególnieniem adresu siedziby jego biura notarialnego (tzw. kantoru). Następnie są wymienione osoby, pomiędzy którymi została zawarta umowa (imiona, otczestwa i nazwiska, status społeczny, miejsce zamieszkania) oraz świadkowie obecni podczas spisania aktu. Notariusz ustala tożsamość przybyłych osób na podstawie przedłożonych pełnomocnictw lub oświadcza, że uczestnicy są mu osobiście znani.

56 Słójka o pow. 728 dziesięcin należała do tzw. majątków instrukcyjnych. Została wytypowana przez władze gubernialne, zgodnie z Instrukcją z 23 lipca 1865 r., na ulgową sprzedaż urzędnikom państwowym i wojskowym rosyjskiego pochodzenia, za zasługi podczas tłumienia powstania styczniowego (patrz: J. Danieluk, Majątki instrukcyjne na ziemiach byłego Wielkiego Księstwa Litewskiego: stan badań oraz postulaty badawcze, „Rocznik Lituanistyczny” 2017, t. 3, s. 239-257.

57 APB, SNSOG, nr zesp. 280, sygn. 293, k. 155-156v.

58 R. Sikorski, op. cit., s. 112. 
W dalszej części dokumentu zapisana jest treść zasadnicza aktu. Przedmiotem umowy kupna-sprzedaży może być posiadłość ziemska (cały majątek lub jego część), geodezyjnie wydzielona działka ziemi lub lasu, dom mieszkalny, budynki gospodarcze. Nierzadko przy zakupie całego majątku ziemskiego odnotowywane jest również mienie ruchome w postaci sprzętu gospodarczego lub domowego, inwentarza żywego i innych. Wyjaśnione są również okoliczności nabycia przez dotychczasowego właściciela sprzedawanej nieruchomości lub majątku ruchomego przez wymienienie wszystkich dokumentów sankcjonujących aktualną własność. Notariusz zobowiązany był uwzględnić ewentualne zadłużenia ciążące na nieruchomości: zobowiązania wobec banku, terminy uiszczania należności kredytowych. W przypadku kiedy własność nieruchomości podlegała ograniczeniom, należało przywołać odpowiednie przepisy prawne (np. Instrukcja z 23 lipca 1865 r. lub Ukaz z 10 grudnia 1865 r. $^{59}$ ). Wówczas notariusz winien był przytoczyć podstawę prawną i wymienić treść konkretnych artykułów regulujących możliwość sprzedaży własności.

Po treści właściwej notariusz zapisuje formułę mówiącą o odczytaniu, zrozumieniu oraz zaakceptowaniu projektu aktu przez uczestników zawarcia transakcji. Ponownie wymienieni zostają z imienia i nazwiska wszyscy biorący udział $\mathrm{w}$ transakcji.

Na końcu umowy odnotowywano wysokość opłat skarbowych oraz należności dla notariusza ze wskazaniem osób, na których ciąży zobowiązanie rozliczenia kosztów wszystkich czynności. Na odwrocie ostatniej strony odciśnięta jest kwadratowa, opisowa pieczęć tuszowa poświadczająca wniesienie opłat urzędowych tzw. poszlin za sporządzenie.

59 Инструкція о порядкп продажи казенньхъ земель въ западныхъ губернях лицамъ русскаго происхожденія, служащ,им в томъ крап или желающимв водворитвся на постоянное жительство, [w:] Сборник правителственныхъ распоряженій по водворенію русскихъ землевладпльцевъ въ Спверо-Западномъ Крап, Вильна 1886, s. 32-38; J. Danieluk, Majątki instrukcyjne na ziemiach byłego Wielkiego Księstwa Litewskiego: stan badań oraz postulaty badawcze, „Rocznik Lituanistyczny” 2017, t. 3, s. 239-257; J. Szumski, Instrukcyjne majątki ziemskie w powiecie sokólskim w latach 1867-1914. Problematyka prawno-własnościowa, [w:] „Studia polsko-litewsko-białoruskie", red. J. Tomaszewski, E. Smułkowa, H. Majecki, Warszawa 1988, s. 69-88; J. Smykowski, Ukaz z 10 XII 1865 r. i jego konsekwencje dla stanu posiadania ziemiaństwa polskiego w zachodnich guberniach Imperium Rosyjskiego, [w:] Wilno i Kresy północno-wschodnie. Materiały z II Międzynarodowej Konferencji w Białymstoku 14-17 IX 1994 r., red. E. Feliksiak, A. Mironowicz, t. 1, Białystok 1996 s. 111-125. 
Ilustracja 5. Umowa sprzedaży działki ziemi o powierzchni około 9,8 ha, położonej w uroczysku „Dubownik”, wchodzącego w skład majątku Słójka, należącego do rzeczywistego radcy stanu Aleksandra Aleksandrowicza Annienkowa - z zasobu Archiwum Państwowego w Białymstoku, Starszy Notariusz Sadu Okregowego w Grodnie, nr zesp, 280, sygnatura: 293, k. 155-156v.

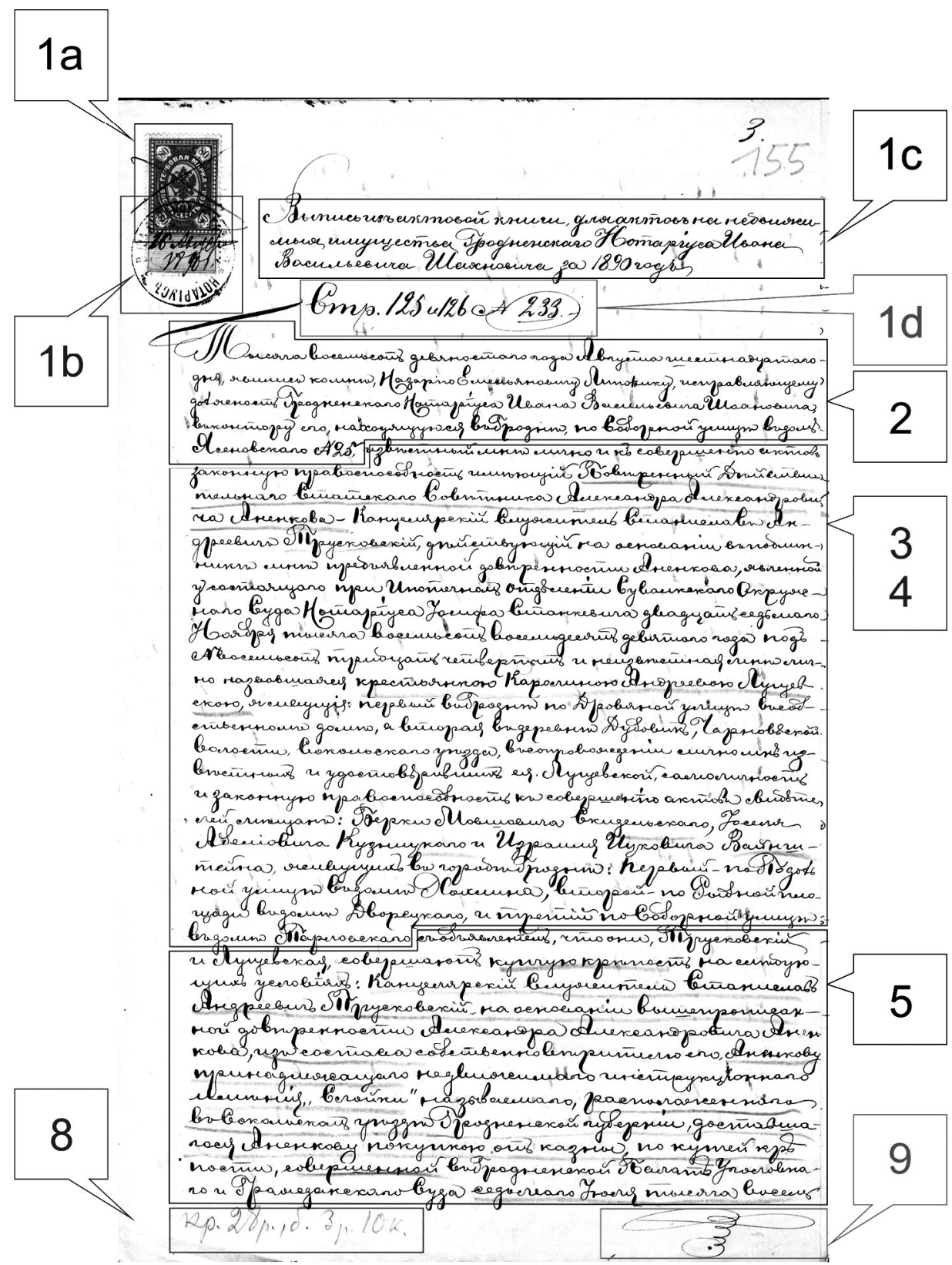


Ilustracja 5

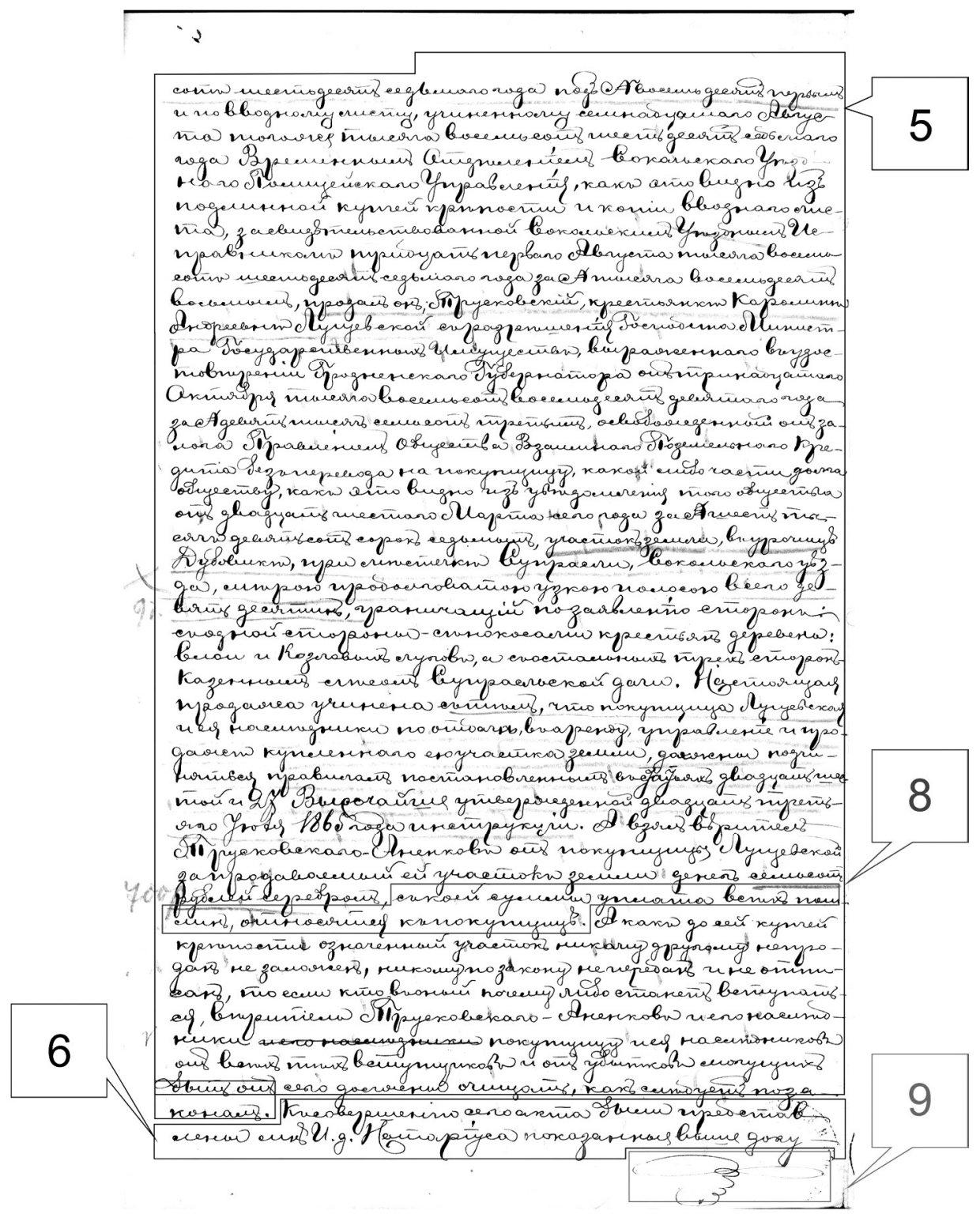


Ilustracja 5

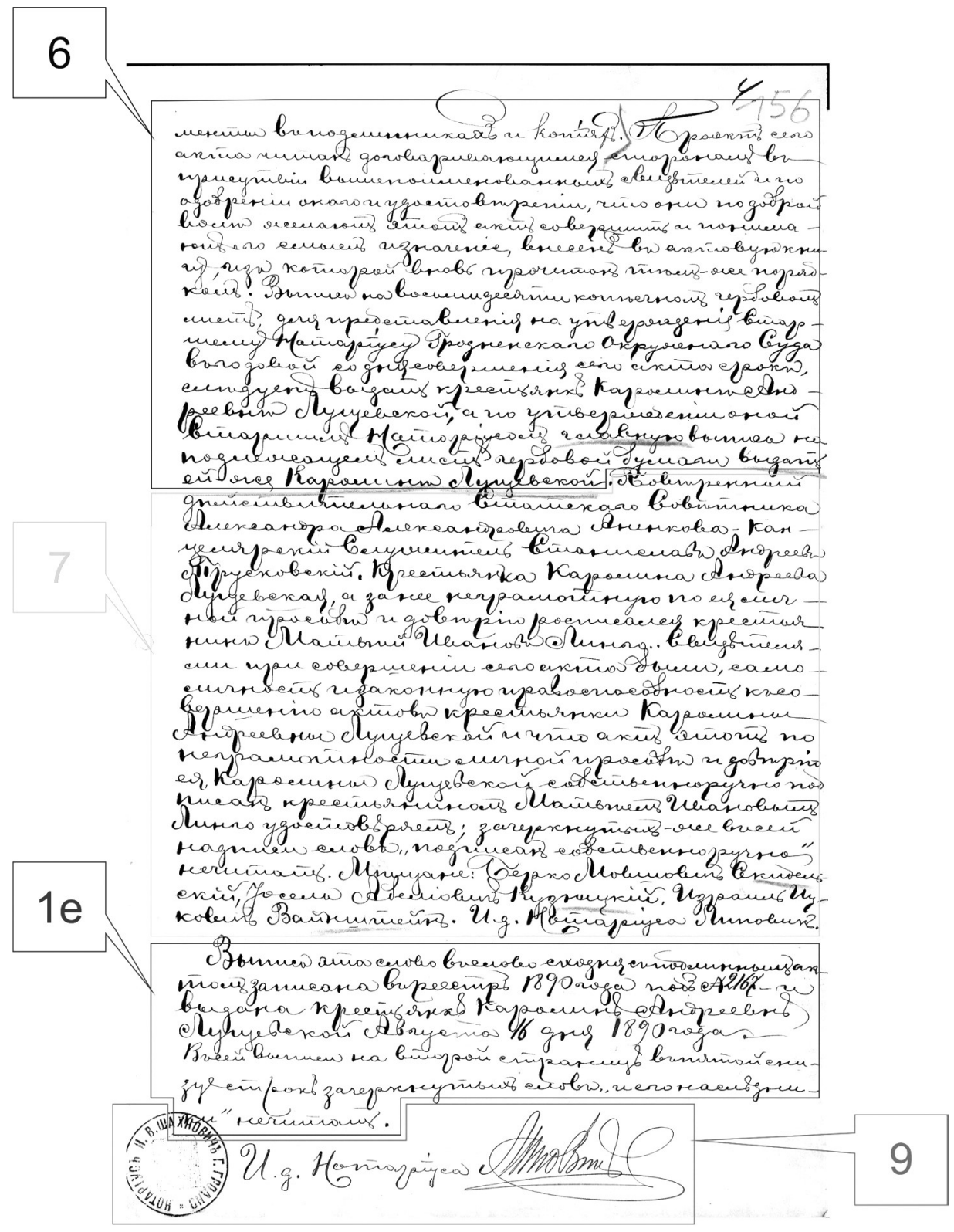


Ilustracja 5

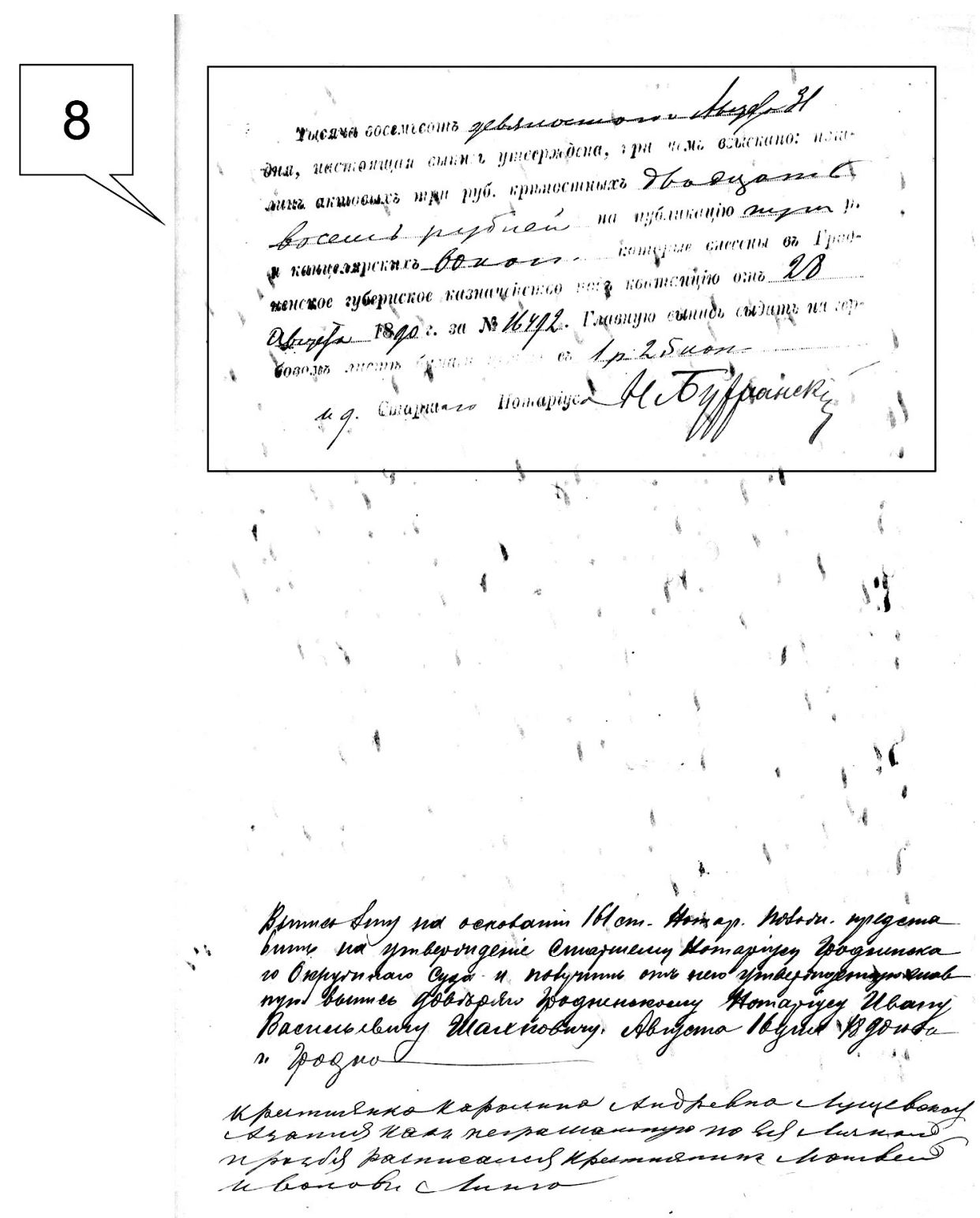

OBJAŚNIENIA (Ilustracja 5):

Ad 1a - znaczek skarbowy (гербовая марка) w wysokości 80 kopiejek. Jest to koszt papieru skarbowego, na którym został wykonany wypis aktu notarialnego.

Ad $1 \mathrm{~b}$ - pieczęć okrągła własnościowa i uwierzytelniająca notariusza grodzieńskiego Iwana Wasiliewicza Szachnowicza z nadpisaną datą wykonania odpisu - 16 sierpnia $1890 \mathrm{r}$.

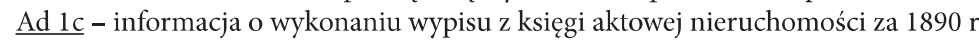

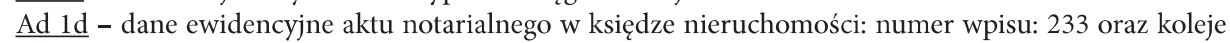
strony z paginacji księgi, na których akt jest zapisany:125 i 126. 
Ad 1e - informacja o tym, że wypis został wpisany „słowo w słowo” do rejestru wieczystego z $1890 \mathrm{r}$. pod numerem 2167 oraz wydany włościance Karolinie Andrejewnie Łuszczewskiej w dniu 16 sierpnia $1890 \mathrm{r}$.

$\underline{\text { Ad } 2}$ - data i miejsce sporządzenia wypisu oraz dane notariusza: 16 sierpień 1890 rok, Nazary Emilianowicz Lipowik, pełniący obowiązki notariusza Iwana Wasiliewicza Szachnowicza. Akt spisano w kantorze notariusza Szachnowicza, zlokalizowanym przy ul. Sobornej w domu Jasienowskiego pod numerem $25 \mathrm{w}$ Grodnie.

Ad. 3-4 - wymienione zostały osoby zawierające transakcję, które są znane notariuszowi: pełnomocnik rzeczywistego radcy stanu Aleksandra Aleksandrowicza Anienkowa - kancelista Stanisław Andrejewicz Truskowski, zam. przy ul. Drowianej w Grodnie we własnym domu, działający na mocy pełnomocnictwa Anienkowa, wystawionego przez notariusza Józefa Stankiewicza, pracownika Wydziału Hipotecznego przy Sądzie Okręgowym w Suwałkach w 27 listopada 1889 r. oraz nieznana notariuszowi włościanka Karolina Andrejewa Łuszczewska, zam. we wsi Dubowik. Następnie wymienionych jest trzech świadków (mieszczan), nieznanych notariuszowi, których tożsamość poświadczyła Łuszczewska: Berko Mowszowicz Skidelski, zam. przy ul. Podolnej w domu Chachlina w Grodnie, Josel Abeliowicz Kuźnicki zam. przy Placu Rybnym w domu Dworeckiego w Grodnie oraz Izrael Ickowicz Wajnsztejn, zam. przy ul. Soborowej w domu Tarłowskiego w Grodnie.

Ad. 5 - pełnomocnik Anienkowa - Truskowski sprzedał działkę ziemi o powierzchni 9 dziesięcin (ok. 9,8 ha) położoną w uroczysku „Dubowik” należącego do majątku instrukcyjnego Słójka, który został nabyty przez obecnego właściciela od państwa podczas transakcji zawartej w Sądzie Głównym w Grodnie 7 lipca $1867 \mathrm{r}$. Właściciel został wprowadzony we własność na mocy tzw. вводного ruста z 17 sierpnia 1867 r., zaświadczonego przez Tymczasowy Oddział Zarządu Policyjnego Powiatu Sokólskiego. Łuszczewska zakupiła działkę za sumę 700 rubli. Nieruchomość była położona w uroczysku „Dubowik” w obrębie następujących granic: $z$ jednej strony łąki należące do wsi: Słoje i Kozłowych Ługów, a z pozostałych trzech stron państwowa „supraska leśna dacza”. Łuszczewska zobowiązana jest przestrzegać zapisów Instrukcji z 23 lipca 1865 r. w zakresie wydzierżawienia, oddania pod zarząd oraz sprzedaży zakupionej działki ${ }^{60}$. Nieruchomość nie została wcześniej nikomu innemu sprzedana, przekazana oraz zastawiona.

Ad. 6 - zamieszczona została informacja o tym, że projekt aktu z załączonymi dokumentami poświadczającymi aktualną własność wraz z pełnomocnictwami został przedłożony notariuszowi i zaakceptowany przez wszystkich uczestników transakcji. Następnie akt zredagowano, odczytano oraz ponownie wymieniono uczestników. Treść dokumentu notariusz wprowadził do księgi aktowej i ponownie odczytał. W ciągu roku umowa zostanie dostarczona Starszemu Notariuszowi Sądu Okręgowego w celu akceptacji. Wypis aktu wydano Karolinie Łuszczewskiej. Natomiast główny wypis nabywczyni nieruchomości otrzyma po akceptacji umowy przez Starszego Notariusza.

$\underline{\text { Ad. } 7}$ - wymienieni zostali wszyscy uczestnicy transakcji, którzy złożyli własnoręczne podpisy. W przypadku osób niepiśmiennych, podpisu dokonywały osoby przez nich wyznaczone. W imieniu Karoliny Łuszczewskiej podpis złożył włościanin Matwiej Iwanow Lipko. Na końcu notariusz nanosi uwagi odnoszące się do skreśleń całych zdań lub pojedynczych wyrazów występujących w treści dokumentu, jednocześnie podając prawidłowy zapis pojedynczego słowa, zdania lub wyrażenia.

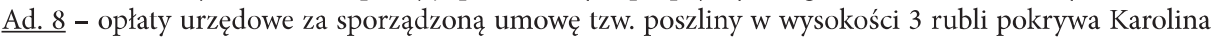
Łuszczewska. Ponadto uiszcza opłatę za nabycie nieruchomości - 28 rubli, za opublikowanie aktu - 3 ruble, koszty kancelaryjne -8 rubli. Wszystkie wymienione sumy zostały wpłacone do grodzieńskiej izby skarbowej.

Ad. 9 - pieczęć okrągła własnościowa i uwierzytelniająca notariusza grodzieńskiego Iwana Wasiliewicza Szachnowicza, obok pieczęci własnoręczny podpis pełniącego obowiązki notariusza Szachnowicza, Nazarego Lipowika.

Ad. 9a - parafa Nazarego Lipowika.

$\overline{60}$ Szczegółowy opis Instrukcji z 23 lipca 1865 r. został zaprezentowany w publikacjach: J. Danieluk, op. cit., s. 239-257; Jerzy Szumski, Instrukcyjne majątki..., s. 69-88. 
Ilustracja 6. Исполнительньй листь. Wprowadzenie ziemianina Iwana Aleksandrowicza Tarasewicza we własność majątku Szyndziel (powiat sokólski), zgodnie z zapisami testamentu dymisjonowanego radcy kolegialnego Mikołaja Filipowa Ułazowskiego zatwierdzonego notarialnie 14 czerwca 1905 r. oraz przez Sąd Okręgowy 15 grudnia 1908 r., - z zasobu Archiwum Państwowego w Białymstoku, Starszy Notariusz Sądu Okręgowego w Grodnie, nr zesp. 280, sygnatura: 350, k. 14.

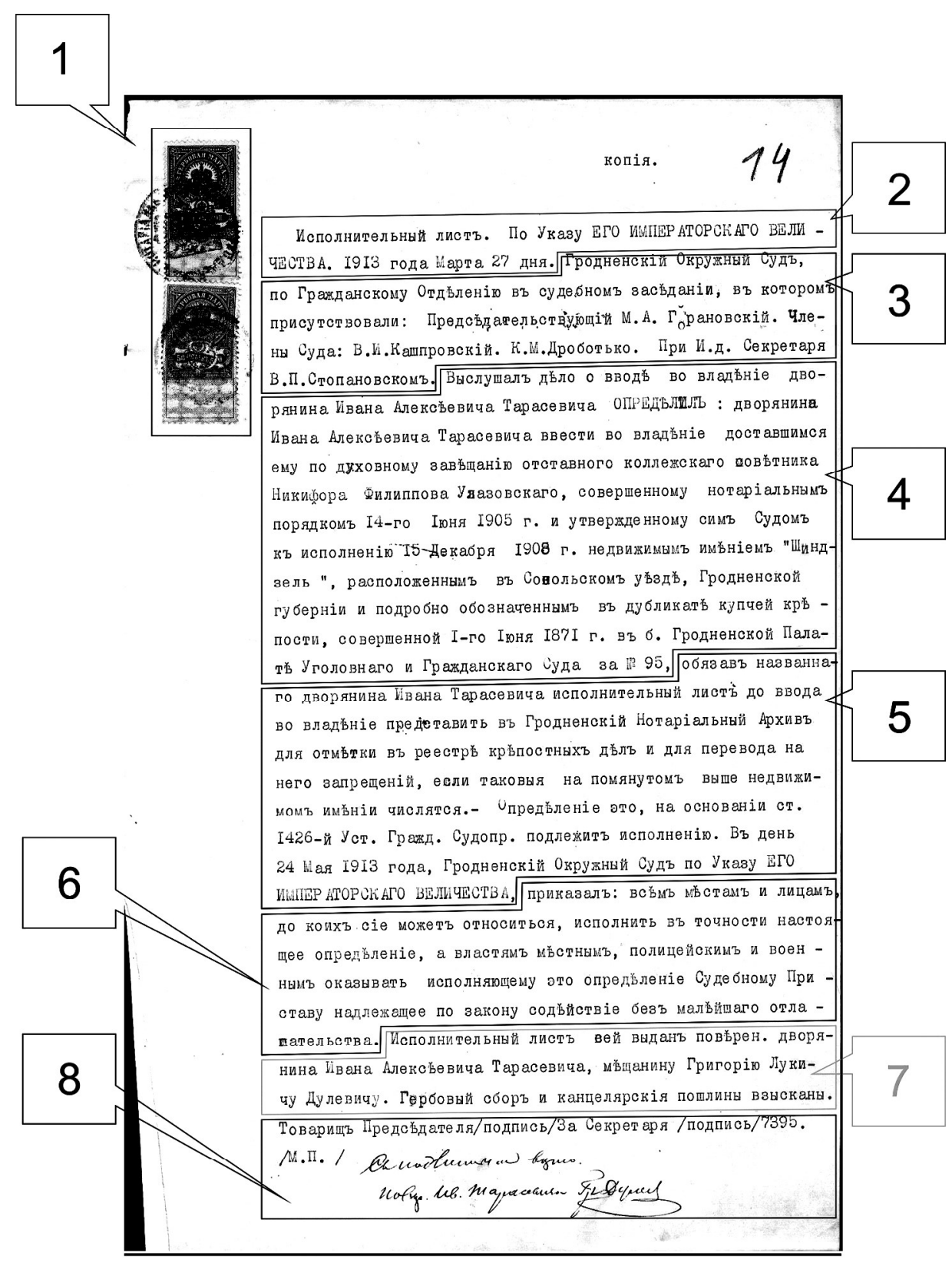




\section{Akt wprowadzający we własność}

Spisanie umowy notarialnej kupna-sprzedaży było jednym z etapów prowadzących do zmiany własności. Wejście w posiadanie nieruchomości (ввод во владение) odbywało się przez wyrok sądowy (ilustracja 6.). Sprawa intromisji należała do kompetencji sądów okręgowych. Wprowadzenie we własność następowała podczas specjalnego sądowego posiedzenia, którego uczestnikami byli: przewodniczący, dwóch członków sądu oraz sekretarz sądowy. W prezentowanym poniżej dokumencie wprowadzającym we własność wymieniona jest osoba, która nabyła nieruchomość oraz dokument, na mocy którego nastąpiło przejęcie własności (umowa kupna-sprzedaży, testament, akt darowizny, akt zastawu i inne). W kolejnej części listu wprowadzającego znajduje się opis nieruchomość lub mienia ruchomego, które jest przedmiotem intromisji. Nabywca zobowiązany jest dostarczyć rzeczony dokument do archiwum Starszego Notariusza, gdzie zostanie zarejestrowany w księdze rejestrów hipotecznych. Na końcu wymienione są osoby, którym jest on wydawany oraz wysokość opłat skarbowych. Akt jest sygnowany przez przewodniczącego posiedzenia sądowego oraz sekretarza.

\section{OBJAŚNIENIA (Ilustracja 6):}

Ad. 1 - Opłata stemplowa za sporządzenie kopii: pierwszy znaczek skarbowy o nominale - 75 kopiejek, drugi - 50 kopiejek.

$\underline{\text { Ad. } 2}$ - tytuł dokumentu i data spisania - Исполнительный листь, 23 marca $1913 \mathrm{r}$.

$\underline{\text { Ad. } 3}$ - miejsce zatwierdzenia dokumentu: siedziba Sądu Okręgowego w Grodnie oraz skład komisji orzekającej w osobach przewodniczącego, dwóch członków sądu oraz sekretarza, wszyscy wymienieni $z$ nazwiska.

Ad. 4 - przedłożenie sprawy o wprowadzenie ziemianina Iwana Aleksandrowicza Tarasewicza we własność majątku Szyndziel, który otrzymał z mocy realizacji testamentu dymisjonowanego radcy kolegialnego Nikifora Filipowa Ułazowskiego, zatwierdzonego przez Sąd Okręgowy w Grodnie w dniu 15 grudnia 1908 r. Opisane są również wcześniejsze okoliczności nabycia majątku przez testatora.

Ad. 5 - informacje o ewidencji i archiwizacji dokumentu: Tarasewicz zobowiązany został do dostarczenia listu wprowadzającego do grodzieńskiego notarialnego archiwum (tzn. archiwum Starszego Notariusza przy Sądzie Okręgowym w Grodnie) w celu jego rejestracji

Ad. 6 - nakaz sądu okręgowego o podporządkowaniu się postanowieniu wszystkim miejscowym władzom policyjnym, wojskowym i administracyjnym.

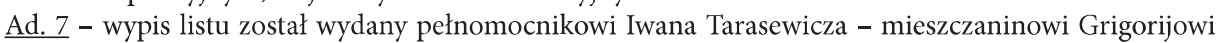
Łukiczu Dulewiczu. Wszelkie opłaty skarbowe i kancelaryjne zostały uiszczone.

Ad. 8 - własnoręczne podpisy przewodniczącego komisji oraz sekretarza sądowego. 


\section{Testament}

Testament jest rodzajem dokumentu, w którym zostało osobiście złożone oświadczenie woli testatora posiadającego pełną zdolnością do czynności prawnych. Ma on charakter jednostronnej i odwołalnej czynności prawnej, przez którą spadkodawca rozporządza swoim majątkiem na wypadek śmierci. Konstytutywną cechą testamentu jest wywoływanie skutków prawnych po śmierci testatora i pod warunkiem, że osoba uprawniona przeżyje spadkodawcę. Testament jest również aktem sformalizowanym, a brak zachowania określonej formy unieważnia czynność testowania. Spowodowane jest to potrzebą zapewnienia autentyczności testamentu i gwarancji, że został sporządzony dla wywołania określonych skutków prawnych ${ }^{61}$.

Testament notarialny ${ }^{62}$ jest dokumentem publicznym i pisemnym, sporządzonym przez spisanie oświadczenia ostatniej woli spadkodawcy w formie aktu notarialnego. Testator oświadcza swoją wolę przed notariuszem, spisującym akt notarialny, który następnie jest odczytywany, przyjęty i podpisany przez spadkodawcę, świadków i notariusza ${ }^{63}$.

Oprócz dyspozycji majątkowych, testator może również zobowiązać spadkobiercę do określonego świadczenia majątkowego na rzecz oznaczonej osoby. Może to być zapis o udziale w nieruchomości lub wypłaceniu określonej wartości spadku osobom wymienionym $\mathrm{w}$ testamencie $\mathrm{w}$ terminie ustalonym przez testatora. Ponadto, spadkodawca może powołać wykonawcę testamentu. Wykonawca taki powinien zarządzać majątkiem spadkowym, spłacać długi spadkowe, a w szczególności wykonywać zapisy i polecenia, a następnie wydać spadkobiercom majątek spadkowy. Do elementów fakultatywnych treści testamentu należą m.in. dyspozycje co do ciała i duszy testatora, polecenia związane z ceremoniałem pogrzebowym, a także rozważania na temat natury ludzkiej, śmiertelności człowieka i konieczności uporządkowania ziemskich spraw ${ }^{64}$.

Struktura testamentu notarialnego nieznaczenie odbiega od budowy umowy notarialnej. Testament sporządzony w formie aktu notarialnego obejmuje następujące segmenty strukturalne:

1) dane nagłówkowe;

2) informacje personalne oraz adresowe notariusza oraz data sporządzenia aktu;

61 A. Dunin-Dudkowska, Akt notarialny..., s. 164-165; B. Żmigrodzka, Testament jako gatunek tekstu, Katowice 1997, s. 11-12.

62 Oprócz testamentu notarialnego występują testamenty: holograficzny - własnoręcznie spisany przez testatora oraz allograficzny - sporządzany przed przedstawicielami administracji państwowej i dodatkowo w obecności dwóch świadków - B. Żmigrodzka, op. cit., s. 13.

63 A. Dunin-Dudkowska, Akt notarialny..., s. 167; B. Żmigrodzka, op. cit., s. 13.

64 B. Żmigrodzka, op. cit., s. 53-54. 
3) informacje personalne testatora;

4) wykaz świadków oraz sposób ustalenia ich tożsamości przez notariusza;

5) dyspozycja: oświadczenie spadkodawcy o powołaniu do całości lub części spadku jednej lub kilku osób z wyszczególnieniem danych osobowych beneficjentów (imię, nazwisko, otczestwo, adres zamieszkania, stopień pokrewieństwa w stosunku do testatora);

6) odczytanie, przyjęcie i podpisanie testamentu notarialnego;

7) postanowienia dotyczące opłat i podatków;

8) tryb realizacji testamentu;

9) poświadczenie notarialne zgodności odpisu z oryginałem.

Analizie został poddany testament Anny Michajłowny Jefimowej, wdowy po rzeczywistym radcy stanu, właścicielki majątku instrukcyjnego Wysoki Stoczek, sporządzony w 1901 r. przez białostockiego notariusza Michała Aleksandrowicza Popowskiego (ilustracja 7) ${ }^{65}$.

65 APB, SNSOG, sygn. 178, k. 21-22v; APB, Sad Okregowy w Bialymstoku. Wydziat Hipoteczny, nr zesp. 251, sygn. 219, k. 24-29. 
Ilustracja 7. Testament Anny Michajłowny Jefimowej, wdowy po rzeczywistym radcy stanu, właścicielki majątku instrukcyjnego Wysoki Stoczek, sporządzony w 1901 r. przez białostockiego notariusza Michała Aleksandrowicza Popowskiego - z zasobu Archiwum Państwowego w Białym-

stoku, Starszy Notariusz Sądu Okręgowego w Grodnie, nr zesp. 280, sygnatura: 178, k. 21-22v.

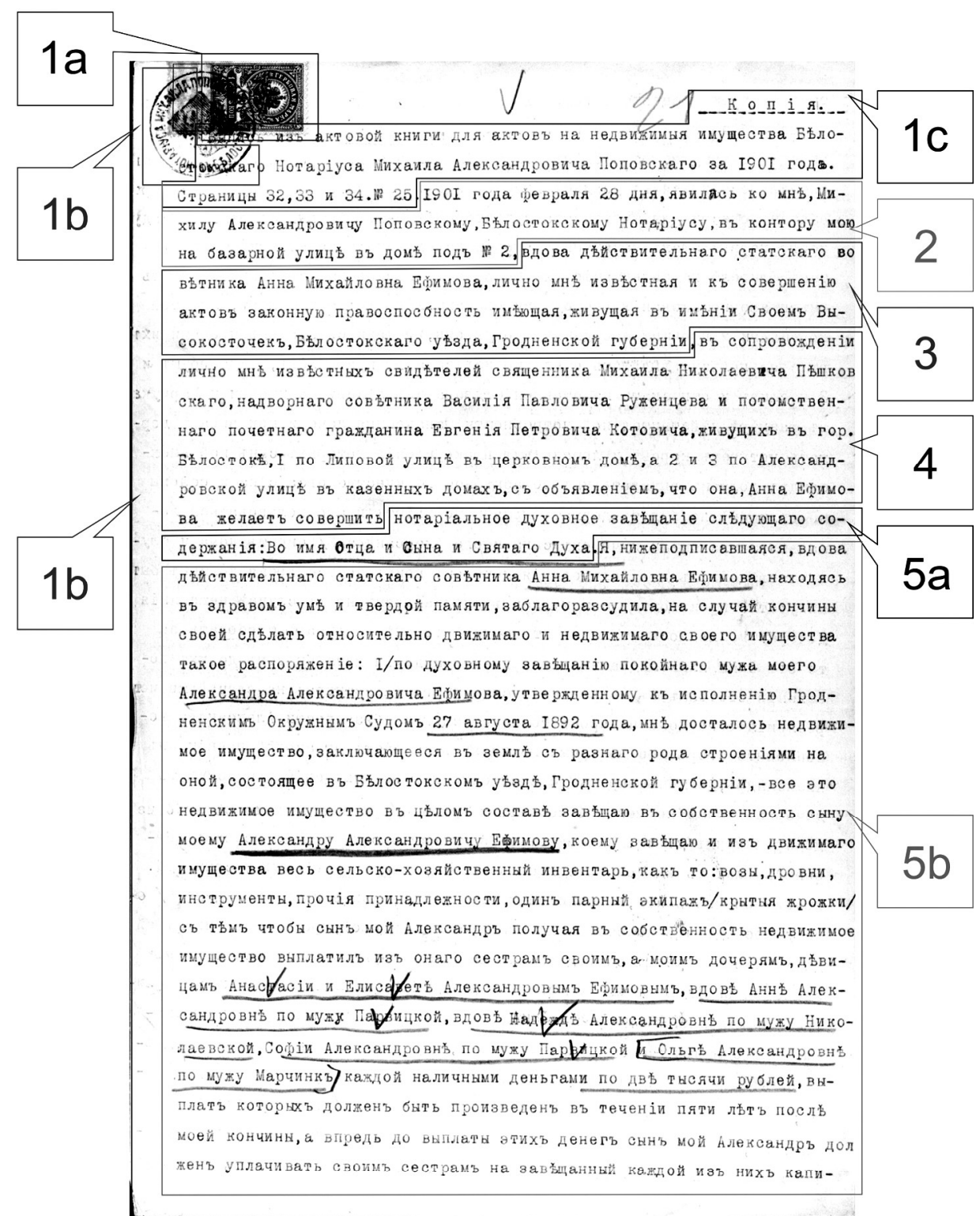


Ilustracja 7.

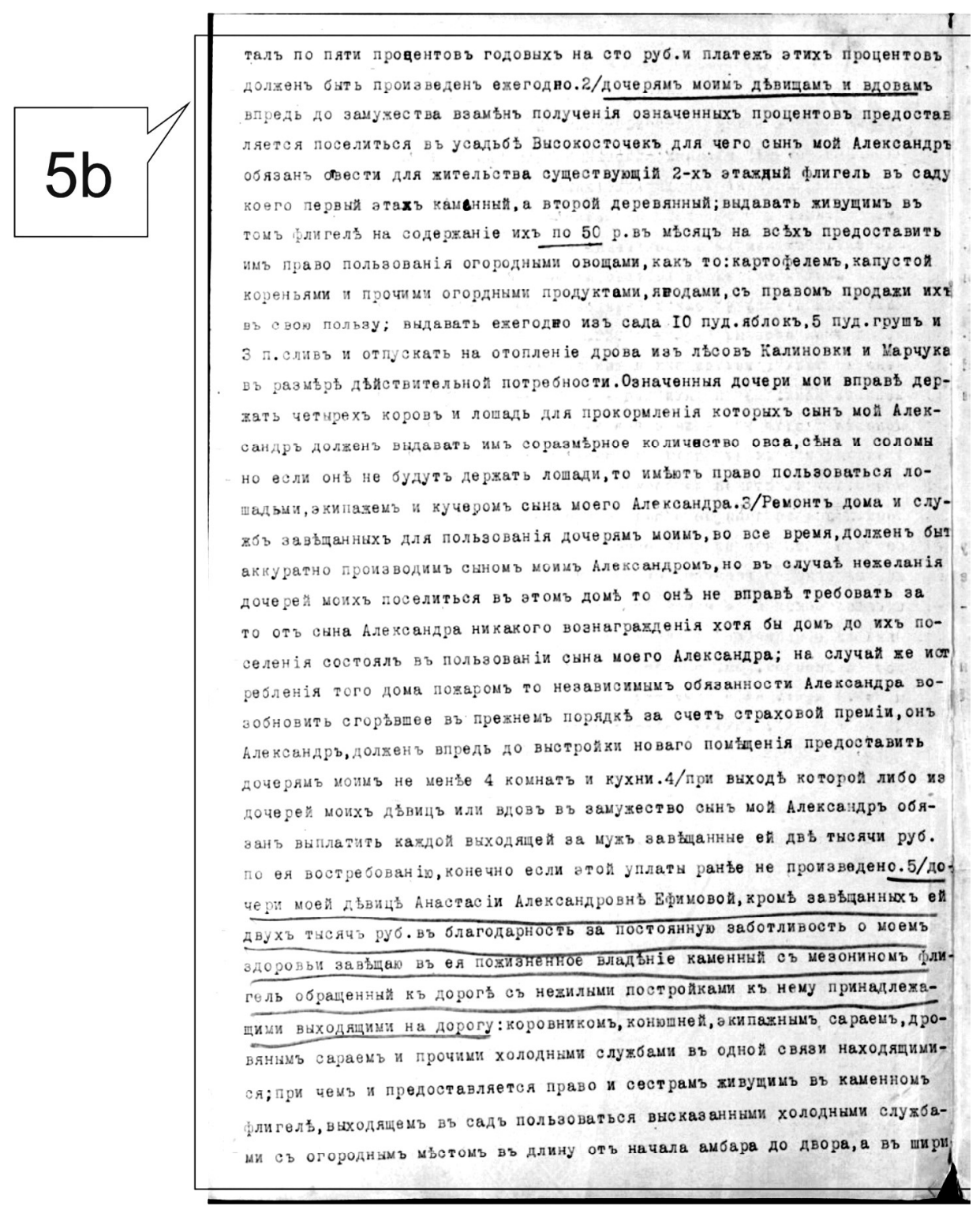


Ilustracja 7.

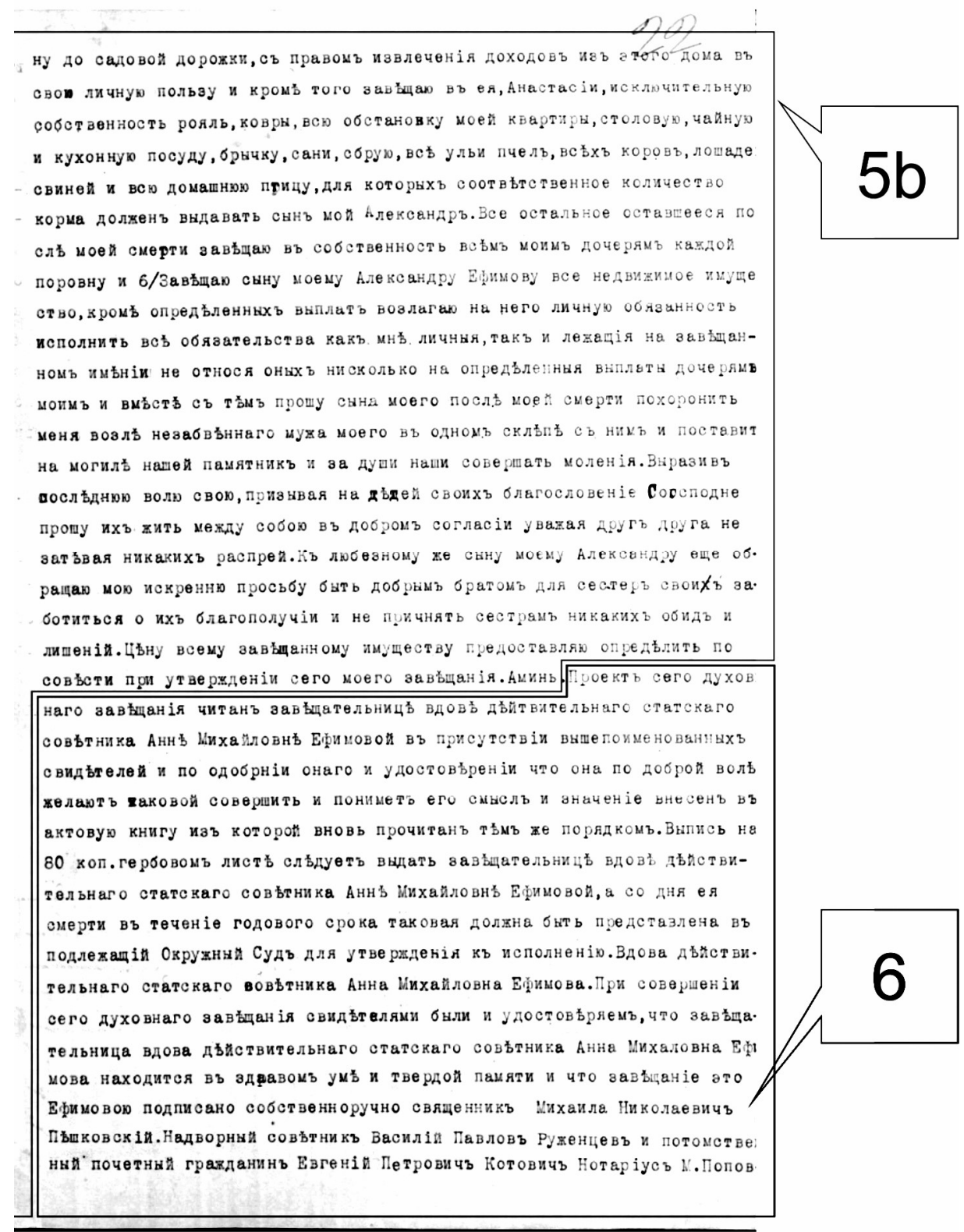


Ilustracja 7.

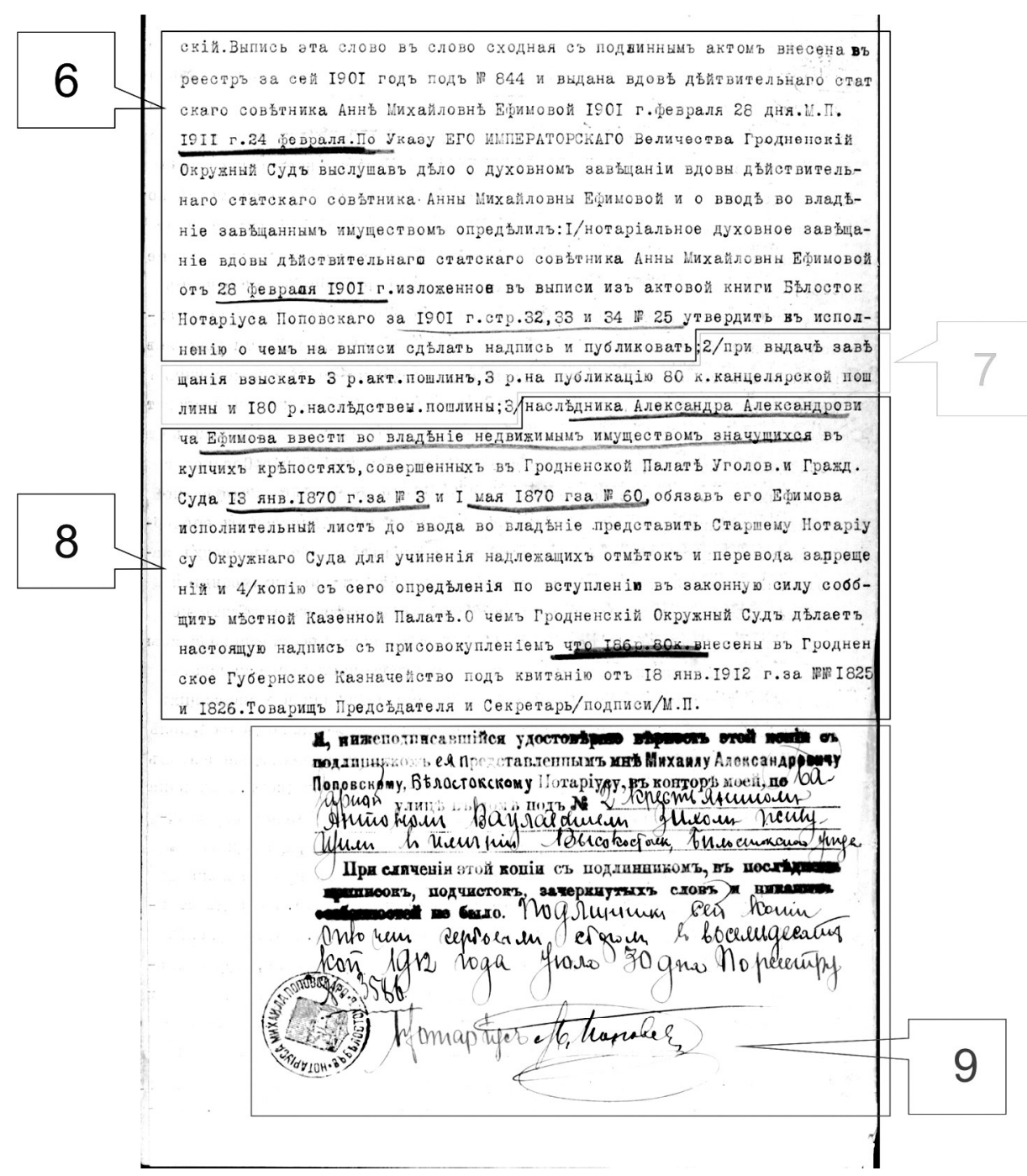




\section{OBJAŚNIENIA (Ilustracja 7):}

Ad. 1a - znaczek skarbowy (гербовая марка) w wysokości 1 rubla i 25 kopiejek. Jest to koszt papieru skarbowego, na którym został wykonany wypis testamentu notarialnego.

$\underline{\text { Ad } 1 \mathrm{~b}}$ - pieczęć okrągła własnościowa i uwierzytelniająca notariusza białostockiego Michaiła Aleksandrowicza Popowskiego.

Ad 1c - informacje ewidencyjne o wypisie z księgi nieruchomości notariusza Popowskiego za $1901 \mathrm{r}$. Podany został numer wpisu: 25 oraz kolejne strony z paginacji księgi, na których akt został zapisany: $32,33,34$.

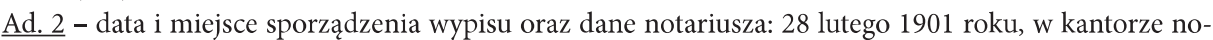
tariusza białostockiego Michaiła Aleksandrowicza Popowskiego znajdującym się przy ul. Bazarnej nr 2 w Białymstoku.

Ad. 3 - spadkodawcą jest znana notariuszowi wdowa po rzeczywistym racy stanu Anna Michajłowna Jefimowa, zamieszkała we własnym majątku Wysoki Stoczek.

Ad. 4 - świadkami transakcji byli: duchowny prawosławny Michaił Nikołajewicz Pieszkowski zam. przy ul. Lipowej na plebanii w Białymstoku, radca dworu Wasilij Pawłowicz Różencew zam. w Białymstoku przy ul. Aleksandrowskiej i honorowy obywatel Jewgienij Pietrowicz Kotowicz, zam. przy ul. Aleksandrowskiej w Białymstoku. Wszyscy świadkowie są znani notariuszowi.

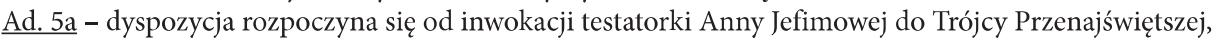
co jest charakterystycznym zwrotem dla tego typu dokumentu. Odwoływanie się do spraw religijnych często miało podkreślić pobożność spisującego testament ${ }^{66}$.

Ad. 5b - dyspozycja jest zapisana w pierwszej osobie liczby pojedynczej. Spadkodawczyni oświadcza, że jest w pełni władz umysłowych i pragnie wyrazić ostatnią wolę, co do postępowania wobec majątku po jej śmierci. W pierwszej części dyspozycji Jefimowa opisuje okoliczności, w jakich została właścicielką majątku Wysoki Stoczek. Przytacza testament swojego męża, Aleksandra Aleksandrowicza Jefimowa, zatwierdzonego 27 sierpnia 1892 r. Testatorka cały swój ruchomy i nieruchomy majątek przepisuje na syna Aleksandra Aleksandrowicza Jefimowa. Następnie spadkodawczyni szczegółowo opisuje całość mienia ruchomego i nieruchomego wchodzącego w skład majątku Wysoki Stoczek. Ponadto spadkodawczyni zobowiązuje Aleksandra, do wypłacenia swoim siostrom: Anastazji i Jelizawiecie Aleksandrownym Jefimowym, wdowie Annie Aleksandrownie po mężu Parwickiej, wdowie Nadziei Aleksandrownie po mężu Nikołajewskiej, Zofii Aleksandrownie po mężu Parwickiej oraz Oldze Aleksandrownie Marczink, po 2 tysiące rubli w ciągu 5 lat liczonych od momentu śmierci Jefimowej. Testatorka w dalszej treści dyspozycji wymienia pomniejsze obowiązki ciążące na Aleksandrze Jefimowie wobec sióstr. Pod koniec dyspozycji właścicielka majątku wyraża prośbę dotyczącą pochówku. Pragnie spocząć obok męża w rodzinnym grobowcu.

Ad. 6 - zamieszczona została informacja o tym, że projekt testamentu został przedłożony notariuszowi i odczytany. Następnie akt został zredagowany, odczytany i zrozumiany przez spadkodawcę. Treść dokumentu notariusz wprowadził do księgi aktowej i ponownie odczytał. Realizacja zapisów testamentu następowała w wyniku orzeczenia sądu okręgowego, po upłynięciu jednego roku od śmierci testatorki. Na końcu świadkowie poświadczają, że testatorka jest w pełni władz umysłowych. Ponownie są wymienieni wszyscy obecni przy sporządzania testamentu.

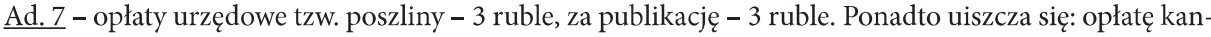
celaryjną - 80 kopiejek oraz opłatę od spadku - 180 rubli. Wszystkie opłaty wynoszące razem 186 rubli i 80 kopiejek trafiają do grodzieńskiej gubernialnej kasy skarbowej.

Ad. 8 - spadkobierca Aleksander Aleksandrowicz Jefimow zobowiązany jest dostarczyć Starszemu Notariuszowi tytuł wykonawczy w celu zatwierdzenia prawa własności do nieruchomości przekazanej w testamencie przez matkę. Odpis decyzji po jej uprawomocnieniu się należy przesłać do izby skarbowej.

Ad. 9 - pieczęć notariusza Popowskiego, poświadczająca zgodności odpisu testamentu z oryginałem sporządzonym 30 lipca $1912 \mathrm{r}$.

$\overline{66}$ K. Wiszowata, Testament jako źródło historyczne, „Białostockie Teki Historyczne” 2007, t. 7, s. 35$-36$ 


\section{Zakończenie}

Reforma systemu notarialnego w Cesarstwie Rosyjskim wprowadzona w 1866 r. nadała większe znaczenie umowom notarialnym, które pełniły rolę dokumentacji hipotecznej. Wypis aktu notarialnego z księgi wieczystej zatwierdzonej przez Starszego Notariusza stawał się dokumentem wiary publicznej i był podstawą do dokonywania wszelkiego rodzaju czynności urzędowych związanych $\mathrm{z}$ daną nieruchomością. W przeciwieństwie do polskiego prawa hipotecznego, w którym moc dokumentów wiary publicznej posiadały tylko oryginalne księgi hipoteczne, a wszystkie wypisy z nich służyły wyłącznie do celów informacyjnych.

Niewysokie koszty spisania aktów notarialnych i powszechna dostępność do kancelarii notarialnych, rozpowszechniło zawieranie transakcji notarialnych w Cesarstwie Rosyjskim. Wprowadzono nadzór nad działalnością notariuszy miejskich i powiatowych przez urząd Starszego Notariusza. Starszy Notariusz zatwierdzał umowy zawarte w kancelariach notarialnych oraz archiwizował dokumentację notarialną wpływającą do jego urzędu. Notariusze otrzymali statut urzędników państwowych, jednak nie przysługiwała im stała pensja oraz emerytura.

Ustawa z 1866 roku ustanawiała nadrzędną pozycję instytucji sądowniczych wobec notariuszy. Notariusze byli rekrutowani przez specjalne komisje powołane spośród członków sądów okręgowych. Z kolei starszy notariusz otrzymywał nominację $\mathrm{z}$ rąk ministra sprawiedliwości. Wprowadzenie we własność nieruchomości odbywało się poprzez decyzję sądu okręgowego.

Zmiany prawne w systemie notarialnych ustalały prawa i obowiązki notariuszy, ujednolicały rodzaje i strukturę ewidencji wytwarzanej w kancelariach notarialnych. Akt normatywny o notariacie z 1866 roku składał się z 218 punktów i spełniał tym samym rolę ,instrukcji”, gdyż szczegółowo opisywał postępowanie urzędnika notarialnego, poczynając od procedury spisania umowy notarialnej, jej uwierzytelnienia i ewidencji poprzez zatwierdzenie aktów w urzędzie starszego notariusza, a na wydawaniu odpisów, wypisów i kopii $z$ akt notarialnych kończąc. 


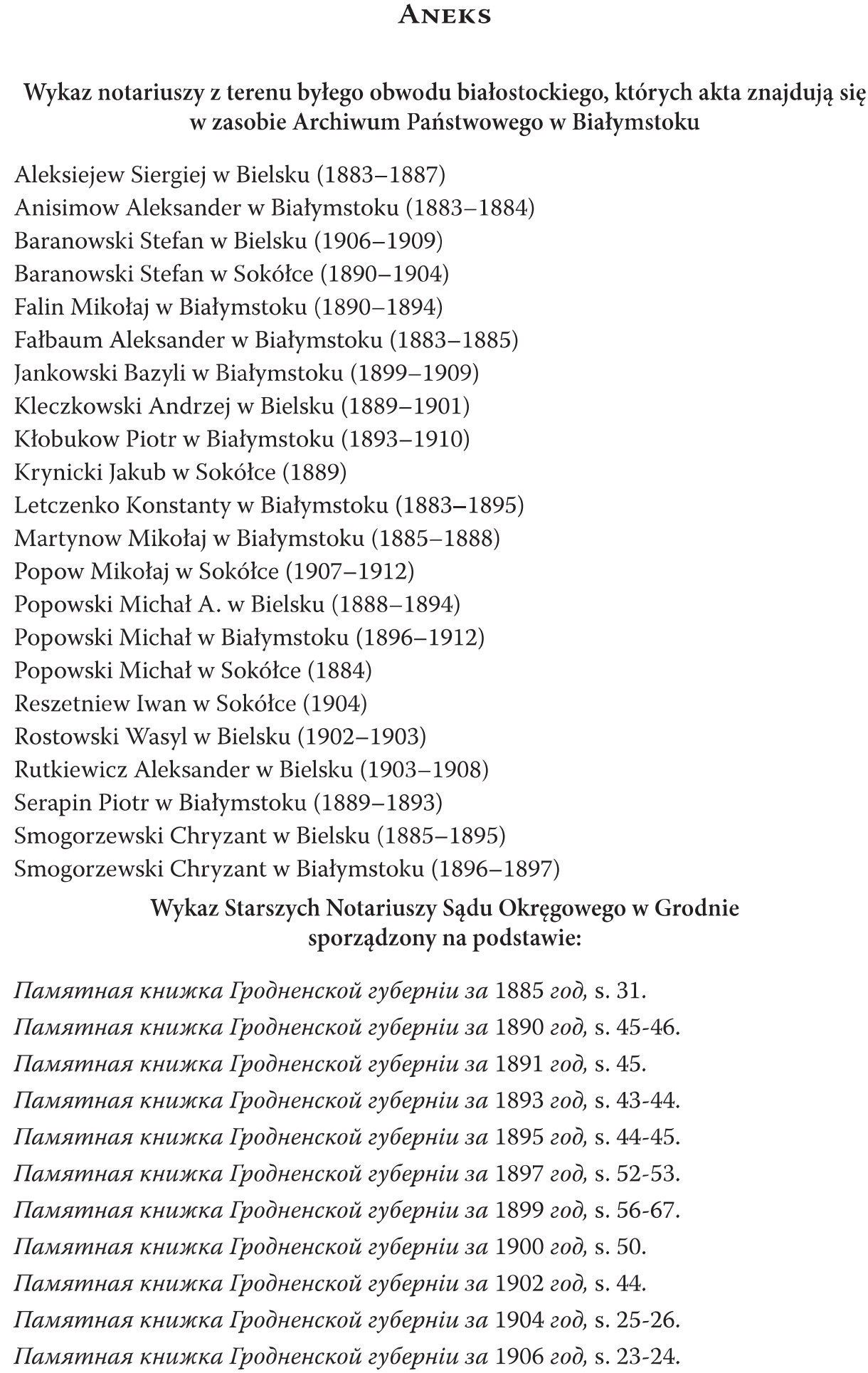


Памятная книжка Гродненской губерніи за 1909 год, s. 102-103.

Памятная книжка Гродненской губерніи за 1910 год, s. 110.

Памятная книжка Гродненской губерніи за 1912 год, s. 109-110.

Памятная книжка Гродненской губерніи за 1913 год, s. 40.

Памятная книжка Гродненской губерніи за 1914 год, s. 42.

Памятная книжка Гродненской губерніи за 1915 год, s. 39-41.

Pisarewski Mikołaj Grigoriewicz - asesor kolegialny, kawaler orderu św. Stanisława III stopnia, starszy notariusz w latach 1883-1888

Prieobrażeński Iwan Pawłowicz - kolegialny asesor, starszy notariusz w latach 1888-1891

Janowski Wasilij Stepanowicz - kolegialny asesor, kawaler orderu św. Stanisława III stopnia, starszy notariusz w latach 1891-1899

Dmitrewski Iwan Pietrowicz - asesor kolegialny, starszy notariusz w latach 1899$-1904$

Dembicki Iwan Mikołajewicz - asesor kolegialny, starszy notariusz w latach 1904$-1909$

Szindler Jarosław Jarosławowicz - asesor kolegialny, starszy notariusz w latach 1909-1913

Misnik Stefan Iwanowicz - radca tytularny, starszy notariusz w latach 1913-1915

Wykaz notariuszy guberni grodzieńskiej z lat 1883-1915

Aleksiejew Sergiej Konstantinowicz - notariusz bielski od 1883 roku

Anisimow Aleksandr Nikołajew - notariusz grodzieński od 1883 roku

Bajraszewski Lucjan Osipowicz - notariusz wołkowyski od 1889 roku

Baranowski Stefan Osipowicz - notariusz sokólski od 1890 roku

Basnin Konstanty Iwanowicz - porucznik kawalerii w rezerwie, notariusz grodzieński od 1883 roku

Bodenr Fryderyk Gawryłowicz - wyznania luterańskiego, notariusz brzeski od 1885 roku

Czubiński Jewgenij Grigoriewicz - notariusz prużański od 1890 roku

Falin Mikołaj Iwanowicz - sekretarz kolegialny, notariusz białostocki od 1883 roku Fałbaum (Folbaum) Aleksander Karlowicz - radca dworu wyznania luterańskiego, notariusz białostocki od 1883 roku

Frisz Oskar Władimirowicz - notariusz grodzieński od 1897 roku

Gazenwinkiel Mikołaj - kolegialny registrator, notariusz grodzieński od 1889 roku Giedrojć-Towscik Josif Iwanowicz - notariusz wołkowyski od 1883 roku Gobjato Aleksander Konstantinowicz - radca tytularny, notariusz brzeski od 1883 roku 
Goriainow Mikołaj Fomicz - radca stanu, notariusz grodzieński od 1883 roku Gorjainow Mikołaj Nikołajewicz - notariusz słonimski od 1887 roku Janowski Wasyl Stepanowicz - notariusz białostocki od 1898 roku Kleczkowski Andrej Andrejewicz - dymisjonowany podpułkownik, kawaler orderu św. Stanisława III stopnia, notariusz bielski od 1895 roku

Kłobukow Piotr Nikołajewicz - sekretarz kolegialny, notariusz białostocki od 1893 roku

Letczenko Konstanty Josifowicz - kolegialny registrator, notariusz białostocki od 1883 roku

Lwow Sergiej Nikołajewicz - notariusz prużański od 1891 roku

Martynow Mikołaj Karlowicz - notariusz białostocki od 1883 roku

Popowski Michaił Aleksandrowicz - notariusz bielski od 1884 roku

Rostowski Wasyl Dmitriewicz - notariusz bielski od 1898 roku

Serapin Piotr - radca tytularny, notariusz białostocki od 1888 roku

Skaballanowicz Płaton Aleksandrowicz - kolegialny registrator, notariusz słonimski od 1884 roku

Smogorzewski Chryzant Jakowlewicz - radca tytularny, kawaler orderu św. Stanisława III stopnia, notariusz bielski od 1906 roku

Szachnowicz Iwan Wasiliewicz - radca tytularny, notariusz grodzieński od 1887 roku

Szczeglatiew Paweł Michajłowicz - porucznik, notariusz brzeski od 1883 roku

Tarnowski Nestor Timofiejewicz - notariusz słonimski od 1884 roku

Tugan-Baranowski Leon Osipowicz - dymisjonowany pułkownik, kawaler orderu św. Włodzimierza IV stopnia, św. Anny III stopnia, św. Stanisława II stopnia otrzymanych za udział w zwalczaniu powstania 1863-1864 roku, notariusz wołkowyski od 1886 roku

Wirski Witold Nikołajewicz - notariusz prużański od 1899 roku

\section{Bibliografia}

\section{Źródła drukowane}

Высочайше утвержденныя основныя положенія преобразованія судебной части вь Россіи, 29 Сентября 1862 года, [w:] Полное собрание законов Российской империи, t. 37 (1862), nr 48761, s. 145-174.

Высочайше утверждненное положеніе о нотаріяльной части 14 Апрпля 1866 года, [w:] Полное собрание законов Российской империи, t. 41 (1866), nr 43186, s. 346-362.

Памятная книжка Гродненской губерніи, 1885-1915.

Archiwalia

Archiwum Państwowego w Białymstoku:

Akta Notariusza Aleksiejewa Siergieja w Bielsku, 1883-1887, nr zesp. 554. 
Akta Notariusza Anisimowa Aleksandra w Białymstoku,1883-1884, nr zesp. 281. Akta notariusza Baranowskiego Stefana w Sokótce, 1890-1904, nr zesp. 303. Akta notariusza Baranowskiego Stepana w Bielsku, 1906-1909, nr zesp. 555. Akta notariusza Falina Mikołaja w Białymstoku, 1890-1894, nr zesp. 284. Akta notariusza Fałbauma Aleksandra w Białymstoku, 1883-1885, nr zesp. 285. Akta notariusza Janowskiego Bazylego w Białymstoku, 1899-1909, nr zesp. 287. Akta notariusza Kleczkowskiego Andrzeja w Bielsku, 1889-1901, nr zesp. 556. Akta notariusza Kłobukowa Piotra w Białymstoku, 1893-1910, nr zesp. 289. Akta notariusza Krynickiego Jakuba w Sokótce, 1889, nr zesp. 306. Akta notariusza Letczenki Konstantego w Bialymstoku, 1883-1895, nr zesp. 292. Akta notariusza Martynowa Mikołaja w Białymstoku, 1885-1888, nr zesp. 293. Akta notariusza Popowa Mikołaja w Sokótce, 1907-1912, nr zesp. 307. Akta notariusza Popowskiego Michała w Bielsku, 1888-1894, nr zesp. 557. Akta notariusza Popowskiego Michała w Białymstoku, 1896-1912, nr zesp. 294. Akta notariusza Popowskiego Michała w Sokółce, 1884, nr zesp. 302. Akta notariusza Reszetniewa Iwana w Sokółce, 1904, nr zesp. 308. Akta notariusza Rostowskiego Wasyla w Bielsku, 1903, nr zesp. 558. Akta notariusza Rutkiewicza Aleksandra w Bielsku, 1903-1908, nr zesp. 559. Akta notariusza Serapina Piotra w Bialymstoku, 1889-1893, nr zesp. 295. Akta notariusza Smogorzewskiego Chryzanta w Bielsku, 1885-1895, nr zesp. 560. Akta notariusza Smogorzewskiego Chryzanta w Biatymstoku, 1896-1897, nr zesp. 296. Sad Okręgowy w Bialymstoku. Wydział Hipoteczny, nr zesp. 561, sygnatura: 219. Starszy Notariusz Sądu Okręgowego w Grodnie, nr zesp. 280, 1882-1915, sygnatury: 134, $178,196,293,350$

\section{Opracowania}

Бажутов К., Судебная реформа 1864 г. - этап в процессе демократизации судебной системы России, [w:] Судебная Реформа 1864 года и ее значение для формирования правовых систем государств постсоветского пространства: пробльемы теории и практики, Материаль XIV Международных Конивских чтений, Владивосток 2015, s. 13-19.

Chojnowski W., Jarzęcki A., Wzory aktów i innych dokumentów notarialnych, Warszawa 1971.

Chwalba A., Imperium korupcji w Rosji i Królestwie Polskim w latach 1861-1917, Kraków 2006.

Danieluk J., Niemiecka rodzina na Podlasiu - Dziedzictwo Artura Hasbacha (1864-1940), [w:] Stan badań nad wielokulturowym dziedzictwem dawnej Rzeczpospolitej, red. W. Walczak i K. Łopatecki, Białystok 2017, s. 243-268.

Danieluk J., Majątki instrukcyjne na ziemiach byłego Wielkiego Księstwa Litewskiego: stan badań oraz postulaty badawcze, „Rocznik Lituanistyczny” 2017, t. 3, s. 239$-257$. 
Drzewiecki H., Zarys dziejów notariatu w Polsce, Warszawa 1927.

Dunin-Dudkowska A., Akta notarialne na tle przemian historyczno-kulturowych w Polsce, „Język a Kultura” 2002, t. 23, s. 135-150.

Dunin-Dudkowska A., Akt notarialny jako gatunek wypowiedzi, Lublin 2010.

Fiedorczyk P., Recenzja pracy: D. Malec, Dzieje notariatu polskiego, „Czasopismo Prawno-Historyczne" 2008, t. LX, z. 2, s. 409-414.

Фемелиди А., Русский нотариат. История нотариата и действующее нотариальное положение 14 апреля 1866 г., Санкт-Петербург 1902.

Góra S., Projekt ustawy notarjatu, „Przegląd Notarialny” 1922, nr 1 s. 9-39.

Grzybowski K., Historia państwa i prawa Polski, t. IV, Warszawa 1982.

Коморов Н., Нотариат в Российской империи во второй половине XIX - начале ХХ века (Историко-правовое исследование), Москва 2004.

Korobowicz A., Witkowski W., Ustrój i prawo na ziemiach polskich, Lublin 1994.

Korobowicz A., Sadownictwo Królestwa polskiego, Lublin 1996.

Kowalska S., Podstawy prawne działania notariuszy kaliskich $w$ okresie międzywojennym, [w:] Dziedzictwo kulturowe miasta Kalisza i regionu południowej Wielkopolski, red. W. Kowalska, Poznań 2012, s. 149-170.

Kozak S., Reprezentacyjność galicyjskich akt notarialnych z zasobu Archiwum Państwowego w Przemyślu, „Archeion” 1997, t. 98, s. 45-65.

Kuryłowicz M., Z historiografii notariatu w Polce, „Rejent” 1999, nr 8 (800), s. 66-77.

Łopatecki K., Zalewska E., Historia uroczyska Jaroszówka. Badania nad przemianami własnościowo-osadniczymi na pograniczu Wasilkowa i Białegostoku, „Studia Podlaskie" 2013, t. 21, s. 68-69.

Łopatecki K., Struktura i siedziba Sądu Głównego w Białymstoku (1808-1842), „Miscellanea Historico-Iuridica" 2017, t. XVI, z. 2, s. 21-40.

Malec D., Dzieje notariatu polskiego, Kraków 2007.

Malec D., Notariat Drugiej Rzeczpospolitej, Kraków 2002.

Nowakowski K., Konferencja metodyczna dotyczaca opracowania akt notarialnych, "Archeion” 1993, t. 92, s. 192-193.

Nowak M., Ruszkowska M., Notariusze sądu okręgowego i sądów pokoju guberni kieleckiej w latach 1876-1915 - próba charakterystyki środowiska, [w:] Dzieje biurokracji na ziemiach polskich, red. A. Górak, Lublin - Siedlce 2008, s. 349-361.

Олейнова А., История становления законодательства о нотариате в России, Москва 2004.

Siegel S., Ceny w Warszawie w latach 1816-1914, Poznań 1949.

Sikorski R., Działalność kancelarii notarialnej pod koniec XIX i w pierwszych latach XX wieku oraz po odzyskaniu niepodległości, w świetle przepisów zachowanej dokumentacji zespołu archiwalnego: Kancelaria notariusza Stanisława Leopolda Biernackiego w Częstochowie, „Ziemia Częstochowska” 2016, t. XLII, s. 109-119 .

Szumski J., Inwentarz Zespołu Akt Starszy Notariusz Sądu Okręgowego w Grodnie, [1581-1882] 1883-1915 [1920-1930], Białystok 2012. 
Szumski J., Instrukcyjne majątki ziemskie w powiecie sokólskim w latach 1867-1914. Problematyka prawno-własnościowa, [w:] „Studia polsko-litewsko-białoruskie”, red. J. Tomaszewski, E. Smułkowa, H. Majecki, Warszawa 1988, s. 69-88.

Smykowski J., Ukaz z 10 XII 1865 r. i jego konsekwencje dla stanu posiadania ziemiaństwa polskiego w zachodnich guberniach Imperium Rosyjskiego, [w:] Wilno i Kresy północno-wschodnie. Materiały z II Międzynarodowej Konferencji w Białymstoku 14-17 IX 1994 r., t. 1, red. E. Feliksiak, A. Mironowicz, Białystok 1996, s. 111-125.

Тишкова О., Положение о нотариальной части, „Гуманитарные и социальные науки" 2011, nr 5, s. 173-185.

Wiszowata K., Testament jako źródło historyczne, „Białostockie Teki Historyczne” 2007, t. 7, s. 25-38.

Wróbel W., Historia ulicy Kijowskiej. Studia z dziejów Białegostoku, Białystok 2011.

Wróbel W., Kilińskiego: historia jednej ulicy, Białystok 2016.

Wróbel M., Antoni Hipolit Wieczorek (1844-1906). Rys biograficzny białostockiego fabrykanta i dzieje jego zakładu (do 1906 r.), „Rocznik Białostocki” 2017, t. XIX, s. 107-137.

Żmigrodzka B., Testament jako gatunek tekstu, Katowice 1997.

\section{Streszczenie}

W artykule przedstawiono mechanizm działania systemu notarialnego na zachodnich ziemiach Cesarstwa Rosyjskiego po przyjęciu tzw. ustawy notarialnej z 1866 r. Zawarty w niej system wyróżniał 2 rodzaje rejentów: Starszych Notariuszy i notariuszy „zwyczajnych”. Starsi notariusze pełnili swoje funkcje w sądach rejonowych. Byli odpowiedzialni za zatwierdzenie umów zawartych przed notariuszami „zwyczajnymi", prowadzenie ksiąg hipotecznych i rejestrów umów notarialnych. Prowadzili także archiwa notarialne, które mieściły się w budynkach sądów. „Zwyczajni” notariusze prowadzili swoje biura notarialne $\mathrm{w}$ miastach prowincjonalnych. Mianowani byli przez prezesów sądów okręgowych i nie musieli posiadać wykształcenia prawniczego, byli jednak zobowiązani do zdania egzaminu przed komisją składającą się z członków miejscowego sądu okręgowego (prezes sądu, starszy notariusz i prokurator). System notarialny, jak widać, był zależny od sądownictwa.

Baza źródłowa, którą wykorzystano do zbadania rosyjskiego notariatu w XIX w. składa się z zespołów archiwalnych Starszego Notariusza w Sądzie Rejonowym w Grodnie przechowywanego w Archiwum Państwowym w Białymstoku. Akty notarialne obejmują terytorium trzech zachodnich powiatów (ujezda) guberni grodzieńskiej (Białystok, Sokółka, Bielsk). Akta archiwalne zawierają różnego rodzaju dokumenty (np. umowy sprzedaży, umowy darowizn, testamenty lub umowy zastawu). Przeanalizowano je pod kątem ich budowy, zasad rejestracji i archiwizacji. 


\section{SUMMARY \\ The functioning of the notary in the Russian Empire by the example of archival records: Senior Notary of the District Court in Grodno}

The paper presents the mechanism of functioning of the notarial system in the western territory of the Russian Empire following introduction of the Notary Act in 1866. The notarial system recognised two categories of notarial officials: senior notaries and regular notaries. Senior notaries officiated in district courts. They were responsible for the approval of notarial agreements that had been drawn up by regular notaries, keeping mortgage records and maintaining registers of notarial transactions. They were also responsible for administrating the notarial archives located in each district court. Regular notaries practiced from notary offices in towns. They were nominated by the president of the district court and were not required to possess a law degree, nevertheless, they were obligated to pass an examination before a commission consisting of members of the local district court (president of the court, senior notary and public prosecutor). As can be seen, the notarial system was wholly dependent on the judiciary.

The source base that was used to study the Russian notary system in the XIX century provides archival background. Records of the Senior Notary of the District Court in Grodno are preserved in the state archive in Bialystok. Notarial acts cover three western districts (ujezda) of the Grodno Governorate (Białystok, Sokołka and Bielsk) and contain a variety of documents - sale agreements, donation agreements, testaments, contracts of pledge and the like). Notarial acts were analysed for their construction, rules of registration and method of archiving. 